\title{
Addition of $N$-aryl imines to alkyne(pentacarbonyl)chromium and tungsten - a novel route to alkenyl(amino)carbene complexes
}

\author{
Mokhles M. Abd-Elzaher ${ }^{1}$, Thomas Froneck, Gerhard Roth, Valentin Gvozdev, \\ Helmut Fischer*
}

Fachbereich für Chemie, Universität Konstanz, Universitätsstraße 10, Fach M727, D-78457 Konstanz, Germany

Received 25 October 1999; accepted 20 December 1999

Dedicated to Professor Dirk Walther on the occasion of his 60th birthday.

\begin{abstract}
Photolysis of $\left[\mathrm{M}(\mathrm{CO})_{6}\right]$ in $\mathrm{CH}_{2} \mathrm{Cl}_{2}$ gives $\left[(\mathrm{CO})_{5} \mathrm{M}\left(\mathrm{CH}_{2} \mathrm{Cl}_{2}\right)\right]\left(\mathrm{M}=\mathrm{Cr}\right.$, W). Replacement of $\mathrm{CH}_{2} \mathrm{Cl}_{2}$ by arylacetylene, $\mathrm{HC} \equiv \mathrm{CC}_{6} \mathrm{H}_{4} \mathrm{R}-p(\mathrm{R}=\mathrm{Me}, \mathrm{H}, \mathrm{Br})$, produces the thermolabile arylacetylene complexes $\left[(\mathrm{CO})_{5} \mathrm{M}\left(\mathrm{HC} \equiv \mathrm{CC}_{6} \mathrm{H}_{4} \mathrm{R}-p\right)\right]$. Addition of $N$-phenyl benzylideneimines, $\mathrm{PhN}=\mathrm{C}\left(\mathrm{C}_{6} \mathrm{H}_{4} \mathrm{R}^{\prime}-p\right) \mathrm{H}\left(\mathrm{R}^{\prime}=\mathrm{Me}, \mathrm{H}, \mathrm{Cl}\right)$, to solutions of these alkyne complexes affords alkeny1(amino)carbene complexes, $\quad\left[(\mathrm{CO})_{5} \mathrm{M}=\mathrm{C}(\mathrm{NPhH}) \mathrm{C}\left(\mathrm{C}_{6} \mathrm{H}_{4} \mathrm{R}-p\right)=\mathrm{C}\left(\mathrm{C}_{6} \mathrm{H}_{4} \mathrm{R}^{\prime}-p\right) \mathrm{H}\right]$, and 2-azetidin-1-ylidene complexes, $\left[(\mathrm{CO})_{5} \mathrm{M}=\mathrm{C}-\mathrm{NPh}-\mathrm{C}\left(\mathrm{C}_{6} \mathrm{H}_{4} \mathrm{R}^{\prime}-p\right) \mathrm{H}-\mathrm{C}\left(\mathrm{C}_{6} \mathrm{H}_{4} \mathrm{R}-p\right) \mathrm{H}\right]$. The formation of the alkenyl(amino)carbene complexes is favored. The ratio alkenyl(amino)carbene/2-azetidin-1-ylidene complex is $2.5-3$ for $\mathrm{M}=\mathrm{W}$ and $6.5-8$ for $\mathrm{M}=\mathrm{Cr}$. Both types of complexes are obtained as mixtures of isomers. The 2-azetidin-1-ylidene complexes are very likely formed by cycloaddition of the imines to the $\mathrm{C}=\mathrm{C}$ bond of vinylidene complexes resulting from tautomerization of the alkyne complexes. The cycloaddition is highly stereoselective. Predominantly, the syn isomer is obtained (syn/anti $\geq 9)$. In contrast, the alkenyl(amino)carbene complexes are presumably derived from the alkyne complexes via cycloaddition of the imines to the coordinated alkyne and subsequent 1,2-hydrogen shift and ring opening. Preferentially, the $E$ isomers (where both aryl substituents are cis with respect to the $\mathrm{C}=\mathrm{C}$ bond) are produced. The structure of the major isomer of the alkenyl(amino)carbene complex $\left[(\mathrm{CO})_{5} \mathrm{~W}=\mathrm{C}(\mathrm{NPhH}) \mathrm{C}\left(\mathrm{C}_{6} \mathrm{H}_{4} \mathrm{Me}-\right.\right.$ $p)=\mathrm{C}(\mathrm{Ph}) \mathrm{H}]$ has been established by X-ray structural analysis. (C) 2000 Elsevier Science S.A. All rights reserved.
\end{abstract}

Keywords: $N$-aryl imines; Alkyne(pentacarbonyl)chromium; Alkyne(pentacarbonyl)tungsten

\section{Introduction}

Vinylidene complexes may be regarded as organometallic analogues of ketenes. Ketenes react with imines by cycloaddition to afford $\beta$-lactams [1]. Analogously, several vinylidene complexes have been shown to readily add imines to the $\mathrm{C}=\mathrm{C}$ bond to form four-membered transition-metal-substituted $N$-heterocycles (Scheme 1). Examples include the formation of 2-azetidin-1-ylidene complexes from $[\mathrm{Cp}(\mathrm{CO})(\mathrm{L}) \mathrm{Fe}=$ $\left.\mathrm{C}=\mathrm{CR}_{2}\right]^{+} \quad\left[\mathrm{L}=\mathrm{P}(\mathrm{OMe})_{3}, \quad \mathrm{PPh}_{3} ; \mathrm{R}=\mathrm{H}, \quad \mathrm{Me}\right] \quad$ and $\mathrm{MeN}=\mathrm{C}(\mathrm{H})$ aryl or thiazolines [2,3], from vinylidene

\footnotetext{
* Corresponding author. Tel.: + 49-7531-882783; fax: + 49-7531883136.

E-mail address: hfischer@dg6.chemie.uni-konstanz.de (H. Fischer)

${ }^{1}$ Present address: Inorganic Chemistry Department, National Research Centre, PO 12622 Dokki, Cairo, Egypt.
}

complexes of manganese and rhenium and imines [4], and from $\left[(\mathrm{CO})_{5} \mathrm{~W}=\mathrm{C}=\mathrm{CPh}_{2}\right]$ and imines [5]. In general, oxidative decomplexation of the four-membered ring yields $\beta$-lactams in moderate to good yields. A vinylidene complex, $\left[(\mathrm{CO})_{5} \mathrm{Cr}=\mathrm{C}=\mathrm{CH}_{2}\right]$, was also proposed as an intermediate in the reactions of pentacarbonyl[hydroxy(methyl)carbene]chromium with dicyclohexyl carbodiimide [6] and of tetramethylammonium acetyl(pentacarbonyl)chromate toluene-4-sulfonyl chloride/ imines [2,7], to give 2-azetidin-1-ylidene complexes (Scheme 1).

Usually, the vinylidene complexes are generated either from carbyne complexes, from acyl complexes or from carbene complexes.

Recently, we observed that reactions of photochemically generated $\left[(\mathrm{CO})_{5} \mathrm{M}\left(\mathrm{CH}_{2} \mathrm{Cl}_{2}\right)\right]$ with phenylacetylene and $\mathrm{N}$-alkyl imines [8] also afforded 2-azetidin-1-yli- 
dene complexes and we proposed the following sequence: (a) substitution of phenylacetylene for coordinated $\mathrm{CH}_{2} \mathrm{Cl}_{2}$; (b) tautomerization of the resulting alkyne complexes $\left[(\mathrm{CO})_{5} \mathrm{M}(\mathrm{HC} \equiv \mathrm{CPh})\right]$ to give the corresponding vinylidene complexes $\left[(\mathrm{CO})_{5} \mathrm{M}=\mathrm{C}=\right.$ $\mathrm{C}(\mathrm{Ph}) \mathrm{H}]$; which (c) are then trapped by the imine as 2-azetidin-1-ylidene complexes.

We now report that the corresponding reactions of $\left[(\mathrm{CO})_{5} \mathrm{M}\left(\mathrm{CH}_{2} \mathrm{Cl}_{2}\right)\right]$ with arylacetylene and $N$-aryl imines essentially take a different course giving rise to the formation of alkenyl(amino)carbene complexes.

\section{Results and discussion}

Addition of arylacetylenes at $-80^{\circ} \mathrm{C}$ to solutions of $\left[(\mathrm{CO})_{5} \mathrm{M}\left(\mathrm{CH}_{2} \mathrm{Cl}_{2}\right)\right]$ freshly prepared by irradiation of the metal hexacarbonyls $\left[\mathrm{M}(\mathrm{CO})_{6}\right]$ in dichloromethane at $-85^{\circ} \mathrm{C}$ afforded the arylacetylene(pentacarbonyl) complexes 1-3 via replacement of the coordinated dichloromethane by alkynes (Scheme 2). Subsequent reaction of 1-3 with two equivalents of $N$-phenyl ben-

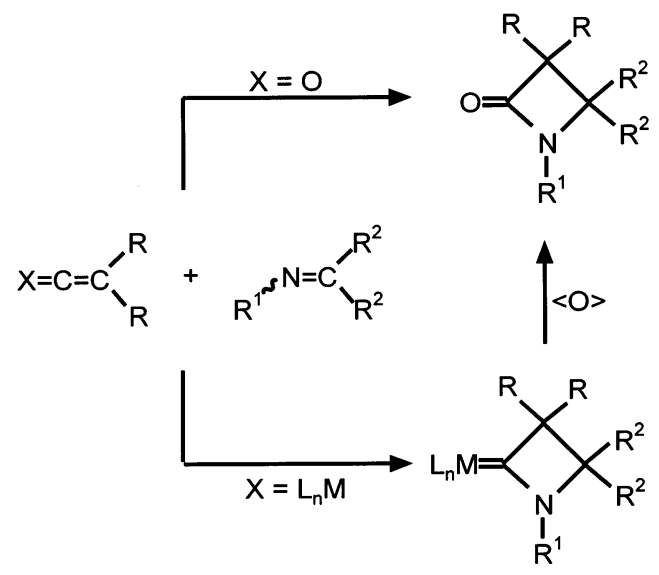

Scheme 1.

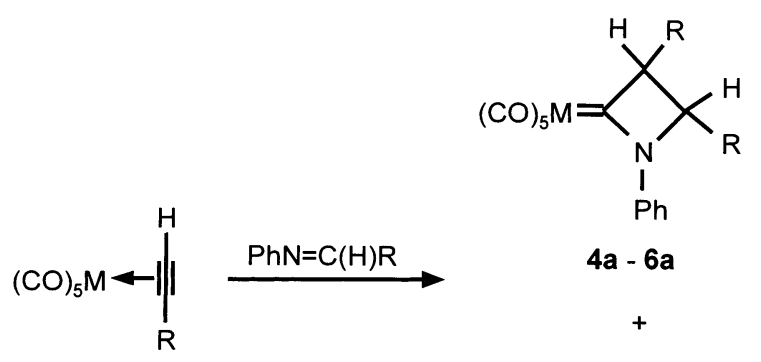

$1-3$

1, 4: $M=W, R=P h$

2, 5: $M=W, R=$ Tol

3, 6: $M=C r, R=P h$

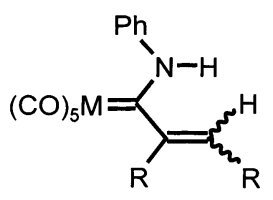

$4 b-6 b$ zylideneimine and $N$-phenyl $p$-methylbenzylideneimine, respectively, yielded isomeric mixtures of the (expected) 2-azetidin-1-ylidene complexes $\mathbf{4 a - 6 a}$ and the (rather unexpected) alkenyl(amino)carbene complexes $\mathbf{4 b}-\mathbf{6 b}$ (Scheme 2). Independent of the substituent and the metal, predominantly the alkenyl(amino)carbene complexes were formed. Within error limits, the yield ratios $\mathbf{4 b} / \mathbf{4 a}$ and $\mathbf{5 b} / \mathbf{5} \mathbf{a}$ were the same (about 2.5). However, substitution of chromium for tungsten more strongly favored the formation of the alkenyl(amino)carbene complex $(\mathbf{6 b} / \mathbf{6 a}=6.5)$.

The ${ }^{1} \mathrm{H}-\mathrm{NMR}$ data indicated that after chromatographic work-up the 2-azetidin-1-ylidene complexes $4 \mathbf{a}-6 \mathbf{a}$ were obtained as mixtures of two stereoisomers (syn and anti), which could not be separated by column chromatography. The resonances of the protons bonded to the ring $\mathrm{C}$ (aryl) atoms of the major isomer appeared as doublets at $\delta=6.51-6.64$ and $4.53-4.67$ ppm $\left({ }^{3} J_{\mathrm{H}, \mathrm{H}}=4.6-4.7 \mathrm{~Hz}\right.$, each), suggesting a syn arrangement of these protons. The coupling constant for the corresponding signals of the minor isomer at $\delta=$ $5.74-5.83$ and $3.94-4.10$ ppm was ${ }^{3} J_{\mathrm{H}, \mathrm{H}}=1.7 \mathrm{~Hz}$, establishing that these protons were anti to each other. Therefore, the thermodynamically less stable syn isomers dominated in each case.

The syn/anti ratio increased only slightly both with the substituent $\mathrm{R}(\mathrm{M}=\mathrm{W}$ : syn $/$ anti $=84: 16[\mathrm{R}=\mathrm{Ph}]$, $90: 10[p$-Tol $]$ and the metal $(\mathrm{R}=\mathrm{Ph}:$ syn $/$ anti $=84: 16$ [W], 80:20 [Cr]).

The alkenyl(amino)carbene complexes were similarly obtained as mixtures of two isomers. Presumably, the isomers differed by the arrangement of the substituents at the $\mathrm{C}=\mathrm{C}$ bond. The ratio of isomers was about $9: 1$. Predominantly, the $E$ isomers (both aryl substituents are mutually cis) were formed as deduced from the ${ }^{1} \mathrm{H}-\mathrm{NMR}$ chemical shifts for $=\mathrm{CH}$ based on the anisotropy of the vicinal aryl substituent and the X-ray structural analysis of $\mathbf{1 1 b}$.

When alkynes and benzylideneimines with different para substituents at the aryl groups were employed, the formation of only one regioisomer of the 2-azetidin-1ylidene complexes and the alkenyl(amino)carbene complexes was observed. In all cases, the aryl substituent of the alkyne ended up at the $\mathrm{C} 4$ position of the 2-azetidin-1-ylidene complex and at the $\mathrm{C}_{\alpha}$ position (adjacent to the carbene carbon) of the $\mathrm{C}=\mathrm{C}$ bond in the alkeny1(amino)carbene complexes (Scheme 3).

The yields of $\mathbf{9 a}-\mathbf{1 4 a}$ and $\mathbf{9 b}-\mathbf{1 4 b}$ were similar to those of the tungsten complexes $\mathbf{4 a}-\mathbf{5 a}$ and $\mathbf{4 b}-\mathbf{5 b}$. The same applied to the chromium complexes $15 \mathbf{a}-17 \mathbf{a}$ and $15 \mathbf{b}-\mathbf{1 7 b}$. The ratios of alkenyl(amino)carbene complex/2-azetidin-1-ylidene complex were about $3(\mathrm{M}=$ W) and $8 \quad(\mathrm{M}=\mathrm{Cr})$. Usually, two isomeric alkenyl(amino)carbene complexes were formed. The isomeric ratio varied between 7:3 and 9:1. 

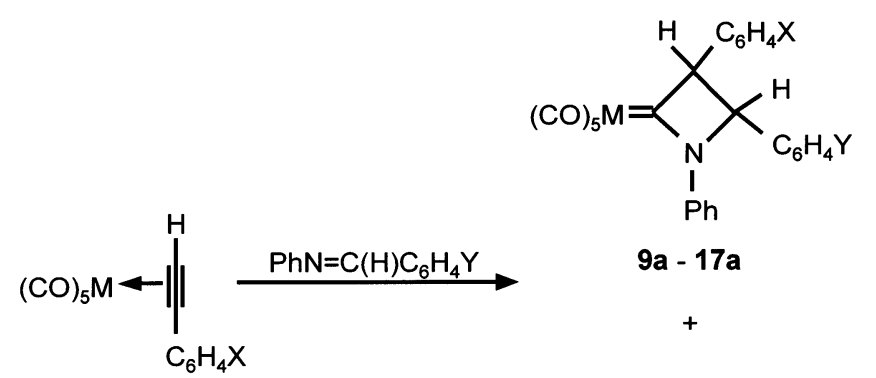

$9 a-17 a$

$+$

$1-3,7,8$

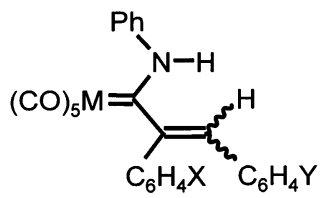

$9 b-17 b$

\begin{tabular}{c|ccccccccc} 
& $1 / 9$ & $1 / 10$ & $2 / 11$ & $3 / 12$ & $7 / 13$ & $7 / 14$ & $3 / 15$ & $8 / 16$ & $8 / 17$ \\
\hline $\mathrm{M}$ & $\mathrm{W}$ & $\mathrm{W}$ & $\mathrm{W}$ & $\mathrm{W}$ & $\mathrm{W}$ & $\mathrm{W}$ & $\mathrm{Cr}$ & $\mathrm{Cr}$ & $\mathrm{Cr}$ \\
$\mathrm{X}$ & $\mathrm{H}$ & $\mathrm{H}$ & $\mathrm{Me}$ & $\mathrm{Me}$ & $\mathrm{Br}$ & $\mathrm{Br}$ & $\mathrm{H}$ & $\mathrm{Me}$ & $\mathrm{Me}$ \\
$\mathrm{Y}$ & $\mathrm{Me}$ & $\mathrm{Cl}$ & $\mathrm{H}$ & $\mathrm{Cl}$ & $\mathrm{H}$ & $\mathrm{Me}$ & $\mathrm{Me}$ & $\mathrm{H}$ & $\mathrm{Cl}$
\end{tabular}

Scheme 3.

Table 1

Selected bond lengths $(\AA)$ and bond angles $\left({ }^{\circ}\right)$ for 11b

\begin{tabular}{lrlr}
\hline Bond lengths & & & \\
$\mathrm{W}(1)-\mathrm{C}(1)$ & $2.044(6)$ & $\mathrm{W}(1)-\mathrm{C}(2)$ & $2.040(6)$ \\
$\mathrm{W}(1)-\mathrm{C}(3)$ & $2.041(6)$ & $\mathrm{W}(1)-\mathrm{C}(4)$ & $2.027(6)$ \\
$\mathrm{W}(1)-\mathrm{C}(5)$ & $2.024(7)$ & $\mathrm{W}(1)-\mathrm{C}(6)$ & $2.239(6)$ \\
$\mathrm{C}(6)-\mathrm{C}(7)$ & $1.503(7)$ & $\mathrm{C}(6)-\mathrm{N}(1)$ & $1.324(6)$ \\
$\mathrm{C}(7)-\mathrm{C}(8)$ & $1.362(8)$ & $\mathrm{C}(7)-\mathrm{C}(21)$ & $1.479(7)$ \\
$\mathrm{C}(8)-\mathrm{C}(31)$ & $1.476(8)$ & $\mathrm{N}(1)-\mathrm{C}(11)$ & $1.439(6)$ \\
$\mathrm{C}(11)-\mathrm{C}(12)$ & $1.379(9)$ & & \\
Bond angles & & & \\
$\mathrm{C}(1)-\mathrm{W}(1)-\mathrm{C}(5)$ & $87.7(3)$ & $\mathrm{C}(2)-\mathrm{W}(1)-\mathrm{C}(5)$ & $89.4(3)$ \\
$\mathrm{C}(3)-\mathrm{W}(1)-\mathrm{C}(5)$ & $84.5(3)$ & $\mathrm{C}(4)-\mathrm{W}(1)-\mathrm{C}(5)$ & $89.2(2)$ \\
$\mathrm{C}(1)-\mathrm{W}(1)-\mathrm{C}(6)$ & $91.4(2)$ & $\mathrm{C}(2)-\mathrm{W}(1)-\mathrm{C}(6)$ & $86.4(2)$ \\
$\mathrm{C}(3)-\mathrm{W}(1)-\mathrm{C}(6)$ & $96.6(2)$ & $\mathrm{C}(4)-\mathrm{W}(1)-\mathrm{C}(6)$ & $95.1(2)$ \\
$\mathrm{C}(5)-\mathrm{W}(1)-\mathrm{C}(6)$ & $175.7(2)$ & $\mathrm{W}(1)-\mathrm{C}(6)-\mathrm{C}(7)$ & $121.6(3)$ \\
$\mathrm{W}(1)-\mathrm{C}(6)-\mathrm{N}(1)$ & $128.7(4)$ & $\mathrm{C}(7)-\mathrm{C}(6)-\mathrm{N}(1)$ & $109.2(5)$ \\
$\mathrm{C}(6)-\mathrm{C}(7)-\mathrm{C}(8)$ & $118.6(5)$ & $\mathrm{C}(6)-\mathrm{C}(7)-\mathrm{C}(21)$ & $116.7(5)$ \\
$\mathrm{C}(8)-\mathrm{C}(7)-\mathrm{C}(21)$ & $124.6(5)$ & $\mathrm{C}(7)-\mathrm{C}(8)-\mathrm{C}(31)$ & $129.9(5)$ \\
$\mathrm{C}(6)-\mathrm{N}(1)-\mathrm{C}(11)$ & $128.9(5)$ & $\mathrm{N}(1)-\mathrm{C}(11)-\mathrm{C}(12)$ & $117.9(5)$ \\
$\mathrm{N}(1)-\mathrm{C}(11)-\mathrm{C}(16)$ & $120.5(5)$ & $\mathrm{C}(7)-\mathrm{C}(21)-\mathrm{C}(22)$ & $121.9(5)$ \\
$\mathrm{C}(7)-\mathrm{C}(21)-\mathrm{C}(26)$ & $120.2(4)$ & $\mathrm{C}(8)-\mathrm{C}(31)-\mathrm{C}(32)$ & $117.4(5)$ \\
$\mathrm{C}(8)-\mathrm{C}(31)-\mathrm{C}(36)$ & $124.9(5)$ & & \\
& & &
\end{tabular}

The structure of the major isomer of the alkenyl(amino)carbene complex 11b obtained from $\left[(\mathrm{CO})_{5} \mathrm{~W}(\mathrm{HC} \equiv \mathrm{CTol}-p)\right]$ and $\mathrm{PhN}=\mathrm{C}(\mathrm{H}) \mathrm{Ph}$ was established by an X-ray structural analysis (Table 1 and Fig. 1).

The most important features of the structure of $\mathbf{1 1 b}$ are

1. the mutual cis orientation of both aryl groups at the $\mathrm{C}_{\alpha}=\mathrm{C}_{\beta}$ bond;
2. the attachment of the $p$-tolyl group to the $\mathrm{C}_{\alpha}$ atom;

3. the strong deviation of the carbene and the olefinic plane from coplanarity (torsion angle $\mathrm{W}(1)-\mathrm{C}(6)$ $\mathrm{C}(7)-\mathrm{C}(8) 120.6(4)^{\circ}$; for a projection of the molecule along the $\mathrm{C}(6)-\mathrm{C}(7)$ axis see Fig. 2) and;

4. the $Z$ orientation of the phenyl group at the partial $\mathrm{C}(6)-\mathrm{N}(1)$ double bond (1.324(6) $\AA$ ).

The carbene carbon is planar coordinated (sum of angles: $359.5^{\circ}$ ). However, the formation of an extended $\mathrm{W}(1)-\mathrm{C}(6)-\mathrm{C}(7)-\mathrm{C}(8) \pi$ system is prevented by the tilt of the olefin against the carbene plane, which is probably due to reduction in steric congestion. As a consequence, the $\mathrm{C}(6)-\mathrm{C}(7)$ bond is rather long (1.503(7) $\AA$ ). The distance compares well with that in carbene complexes with an orthogonal or almost orthogonal arrangement of the carbene and the alkene plane (e.g. $1.511(12) \AA$ in $\left[(\mathrm{CO})_{5} \mathrm{~W}=\mathrm{C}\left(\mathrm{NEt}_{2}\right)-\mathrm{C}\left(\mathrm{CH}=\mathrm{CH}_{2}\right)=\right.$ $\mathrm{C}(\mathrm{H}) \mathrm{C}_{6} \mathrm{H}_{4} \mathrm{Me}-p$ ] (torsion angle $-84.5(11)^{\circ}$ ) [9] and $1.488(8) \AA$ in $\left.\left[(\mathrm{CO})_{5} \mathrm{Cr}=\mathrm{C}(\mathrm{OMe})-\mathrm{C}(\mathrm{Me})=\mathrm{C}(\mathrm{H}) \mathrm{Me}\right][10]\right)$. In contrast, the bond length of the central $\mathrm{C}-\mathrm{C}$ single bond in complexes with a coplanar or an almost coplanar arrangement of the carbene and the alkene plane is usually in the range $1.40-1.47 \AA$ (e.g. 1.427(4) $\AA$ in $\left[(\mathrm{CO})_{5} \mathrm{Cr}=\mathrm{C}\left(\mathrm{NH}_{2}\right)-\mathrm{CH}=\mathrm{C}\left(\mathrm{NMe}_{2}\right) \mathrm{Ph}\right] \quad\{$ torsion angle

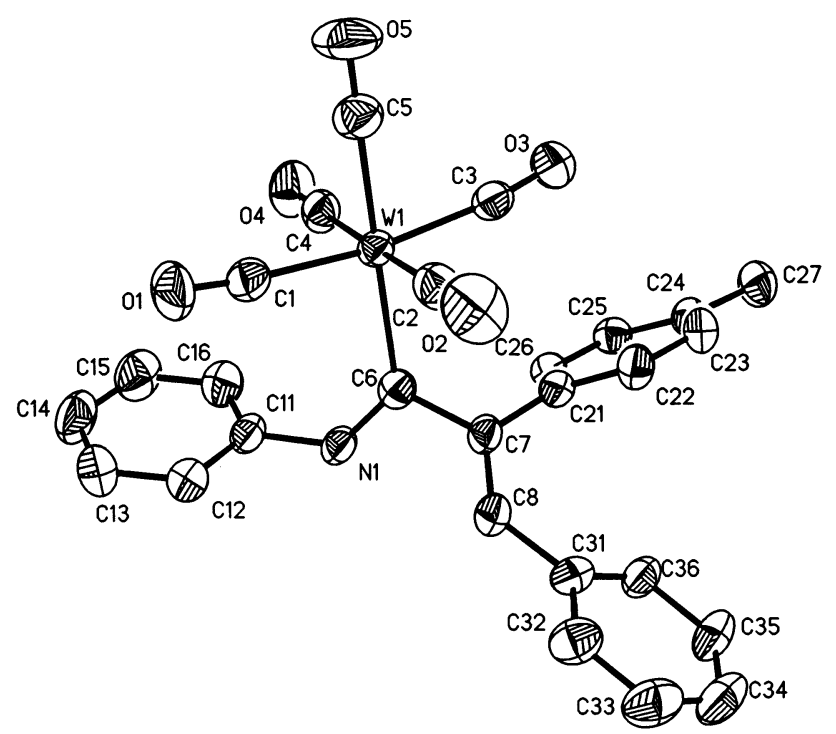

Fig. 1. Structure of the major isomer of complex 11b (hydrogen atoms omitted for clarity).

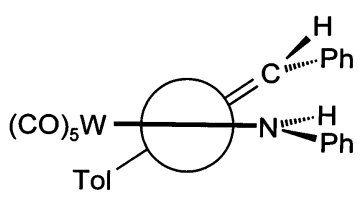

Fig. 2. Projection of complex 11b along the $C(6)-C(7)$ axis. 


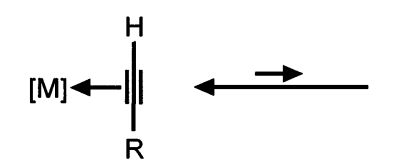<smiles>[R]/C=C(\[R])C=[C]</smiles>

(a) $\ \mathrm{PhN}=\mathrm{C}(\mathrm{H}) \mathrm{R}^{\prime}$
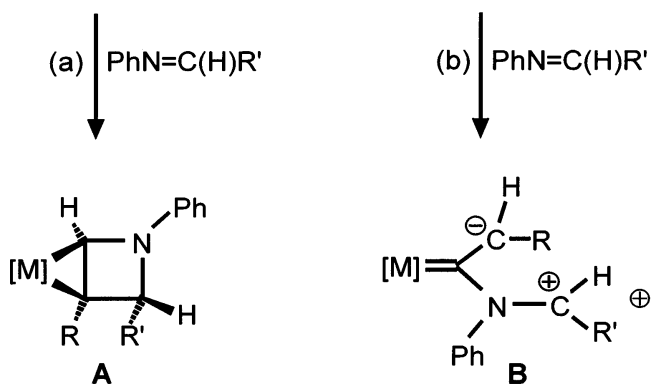

$\downarrow$
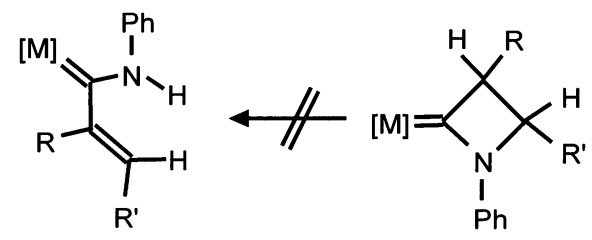

Scheme 4

$\left.169.4^{\circ}\right\} \quad[11], \quad 1.418(5) \quad \AA \quad$ in $\left[(\mathrm{CO})_{5} \mathrm{Cr}=\mathrm{C}\{\mathrm{N}=\right.$ $\mathrm{C}(\mathrm{OMe}) \mathrm{Ph}\}-\mathrm{CH}=\mathrm{C}(\mathrm{H}) \mathrm{NMe}_{2}$ ] (torsion angle $175.7^{\circ}$ ) [12] and $1.407(5) \AA$ in $\left[(\mathrm{CO})_{5} \mathrm{Cr}=\mathrm{C}(\mathrm{OEt})-\mathrm{CH}=\right.$ $\left.\mathrm{C}(\mathrm{Ph})\left\{\mathrm{N}\left(\mathrm{CH}_{2}\right)_{4}\right\}\right]$ (torsion angle $173.0^{\circ}$ ) [13]). To reduce unfavorable steric interaction the planes at $\mathrm{N}(1)$ and $\mathrm{C}_{\alpha}$ are strongly tilted against the carbene plane (torsion angles: $\mathrm{C}(6)-\mathrm{C}(7)-\mathrm{C}(21)-\mathrm{C}(22) \quad 123.6(6)^{\circ}$, $\left.\mathrm{C}(6)-\mathrm{N}(1)-\mathrm{C}(11)-\mathrm{C}(12)-110.7(7)^{\circ}\right)$. As is usually observed with $(\mathrm{CO})_{5} \mathrm{M}$-carbene complexes, the carbene plane bisects the adjacent $\mathrm{OC}-\mathrm{W}-\mathrm{CO}$ angle (torsion angle $\left.\mathrm{C}(3)-\mathrm{W}(1)-\mathrm{C}(6)-\mathrm{C}(7) 40.6(4)^{\circ}\right)$.

The 2-azetidin-1-ylidene complexes are presumably formed by tautomerization of the alkyne complexes to vinylidene complexes, addition of the $N$-aryl benzylideneimine to the metal-bound vinylidene carbon atom and subsequent ring-closure (Scheme 4 , route (b)). A similar mechanism has already been proposed for the formation of 2-azetidin-1-ylidene complexes from $\left[(\mathrm{CO})_{5} \mathrm{~W}\right.$ (alkyne)] complexes and $\mathrm{N}$-alkyl imines [8]. Although it was not possible to detect the vinylidene complexes by IR or NMR spectroscopy, the presence of the vinylidene complex tautomers in solution is plausible on the basis of trapping experiments with alcohols, ynamines and alkoxyalkynes to give alkoxycarbene [14] and cyclobutenylidene complexes [15], respectively. The cycloaddition is regiospecific. The formation of the regioisomeric 3-azetidin-1-ylidene complexes has not been observed.
It is reasonable to assume that the alkenyl(amino)carbene complexes are derived from the 2-azetidin-1-ylidene complexes either by: (a) deprotonation at $\mathrm{C} 4$, followed by subsequent ring opening and reprotonation at nitrogen; or (b) by 1,3-migration of the proton at $\mathrm{C} 4$ and ring opening. However, both mechanisms disagree with the experimental facts. The transformation of 2-azetidin-1-ylidene complexes into alkenyl(amino)carbene complexes can be induced neither thermally nor by the presence in excess of imines, aniline or NaOMe. When trifluoroacetic acid was added to solutions of $\mathbf{5 a}$, only decomposition of $\mathbf{5 a}$ was observed. The formation of the alkenyl(amino)carbene complex 5b could not be detected. These observations indicate that $\mathbf{5 b}$ is not derived from 5a but rather that in the reaction of $\left[(\mathrm{CO})_{5} \mathrm{M}(\right.$ alkyne) $]$ complexes with $\mathrm{N}$-aryl imines, 2-azetidin-1-ylidene and alkenyl(amino)carbene complexes are formed simultaneously.

A mechanism consistent with all observations is shown in Scheme 4, path (a). Cycloaddition of the imine (very likely in a stepwise fashion) to the carbon-carbon bond of the coordinated alkyne presumably gives the dehydroazetidine $\pi$-complex A. A subsequent 1,2-hydrogen shift and ring opening by an electrocyclic process could finally produce the alkenyl(amino)carbene complexes. The formation of the $Z$ isomer (with respect to the partial $\mathrm{C}$ (carbene)-N bond) is very likely determined in the 1,2-hydrogen shift step, that of the cis isomer (with respect to the $\mathrm{C}=\mathrm{C}$ bond) presumably in the cycloaddition step to form the four-membered ring in A.

In summary, the reactions of imines with terminal alkynes coordinated to $(\mathrm{CO})_{5} \mathrm{M}$-fragments strongly depend on the substituent at nitrogen of the imine. $N$ Alkyl imines exclusively give 2-azetidin-1-ylidene complexes. Other coupling products have so far not been observed. In contrast, in the reactions with the less nucleophilic $N$-aryl imines predominantly alkenyl(amino)carbene complexes are formed and the corresponding 2-azetidin-1-ylidene complexes are obtained in rather small amounts. It is very likely that the type of product is already determined in the initial reaction step and depends on whether the imine adds to the alkyne or the vinylidene tautomer.

Alkenylcarbene complexes are usually prepared either by the classical Fischer route via addition of alkenyl lithium to a metal carbonyl and subsequent alkylation of the resulting metallate [16], by addition of protic nucleophiles to the $\mathrm{C} \equiv \mathrm{C}$ bond of alkynylcarbene complexes $[17,18]$, by insertion of $\pi$-donor substituted alkynes into the $\mathrm{M}=\mathrm{C}$ bond of carbene complexes $[16,19]$ or by cycloaddition of olefins to alkynylcarbene complexes [18]. The synthesis of alkenylcarbene complexes from alkyne complexes and imines constitutes a new approach to this type of carbene complexes. 


\section{Experimental}

\subsection{General}

All operations were performed under an inert atmosphere (nitrogen or argon) by using standard Schlenk techniques. Solvents were dried by refluxing over $\mathrm{CaH}_{2}$ $\left(\mathrm{CH}_{2} \mathrm{Cl}_{2}\right.$, pentane) or sodium-benzophenone ketyl $\left(\mathrm{Et}_{2} \mathrm{O}\right)$ and were freshly distilled prior to use. The silica gel used for chromatography (Baker, silica gel for flash chromatography) was nitrogen saturated. The yields refer to analytically pure compounds and were not optimized. Instrumentation: ${ }^{1} \mathrm{H}-$ and ${ }^{13} \mathrm{C}-\mathrm{NMR}$ spectra were recorded with a Bruker AC 250 or a Bruker WM 250 spectrometer. ${ }^{1} \mathrm{H}-\mathrm{NMR}$ resonances of solutions in $\mathrm{CDCl}_{3}$ are reported relative to TMS, those of solutions in acetone- $d_{6}$ and the ${ }^{13} \mathrm{C}$-NMR-resonances relative to the residual solvent peaks of acetone- $d_{6}$ and $\mathrm{CDCl}_{3}$. If not specifically mentioned, IR and NMR spectra are taken at room temperature (r.t.). IR: Biorad FTS 60 spectrophotometer; MS: Finnigan MAT 312 (EI, 70 eV or FAB, NBOH [3-nitrobenzyl alcohol]). The peaks of the tungsten complexes are listed with respect to ${ }^{184} \mathrm{~W}$. Elemental analyses: Heraeus CHN-O-RAPID. Photolysis reactions were carried out in a duran glass apparatus by using a mercury high pressure lamp (TQ 150, Fa. Heraeus). The imines [20] and $p$-bromophenylacetylene [21] were prepared according to literature procedures.

\subsection{Generation of ( $\eta^{2}$-alkyne)metal complexes $\mathbf{1}-\mathbf{3}, \mathbf{7}$, $\boldsymbol{8}$}

The ( $\eta^{2}$-alkyne)metal complexes $\mathbf{1}$ and $\mathbf{3}$ were generated as described in Ref. [8]; the complexes $\mathbf{2}$, 7, and $\mathbf{8}$ were analogously generated. These ( $\eta^{2}$-acetylene)pentacarbonyl complexes were unstable and quickly decomposed at temperatures above $-20(\mathrm{M}=\mathrm{Cr})$ or $0^{\circ} \mathrm{C}(\mathrm{M}=\mathrm{W})$. Therefore, the highly concentrated solutions containing the $\left(\eta^{2}\right.$-alkyne)pentacarbonyl complexes obtained by these procedures were used immediately for the reactions with imines.

\subsubsection{Pentacarbonyl( $\eta^{2}-p$-tolylacetylene)tungsten (2)}

IR $\left(\mathrm{CH}_{2} \mathrm{Cl}_{2}, 243 \mathrm{~K}\right) v(\mathrm{CO})\left(\mathrm{cm}^{-1}\right): 2085 \mathrm{~m}, 1956 \mathrm{vs \text {, }}$ 1933 sh. ${ }^{1} \mathrm{H}-\mathrm{NMR}\left(\mathrm{CDCl}_{3}, 238 \mathrm{~K}\right): \delta 7.36(\mathrm{~d}, J=8.7$ $\mathrm{Hz}, 2 \mathrm{H}$, aryl), $7.26(\mathrm{~d}, J=8.7 \mathrm{~Hz}, 2 \mathrm{H}$, aryl), 6.03 (s, $1 \mathrm{H}, \equiv \mathrm{CH}), 2.42\left(\mathrm{~s}, 3 \mathrm{H}, \mathrm{CH}_{3}\right) .{ }^{13} \mathrm{C}-\mathrm{NMR}\left(\mathrm{CDCl}_{3}, 238\right.$ $\mathrm{K}): \delta 203.7$ (trans-CO), 196.1 (cis-CO), 139.7, 130.2, 129.6, 122.3 (aryl), 80.4 (=C-Tol), $63.8 \quad(\equiv \mathrm{CH}), 21.6$ (Me).

\subsection{2. ( $\eta^{2}-p$-Bromophenylacetylene)-} pentacarbonyltungsten (7)

IR $\left(\mathrm{CH}_{2} \mathrm{Cl}_{2}, 243 \mathrm{~K}\right) v(\mathrm{CO})\left(\mathrm{cm}^{-1}\right): 2085 \mathrm{~m}, 1958 \mathrm{vs}$, 1937 sh. ${ }^{1} \mathrm{H}-\mathrm{NMR}\left(\mathrm{CDCl}_{3}, 238 \mathrm{~K}\right): \delta 7.62-7.29(\mathrm{~m}$, $4 \mathrm{H}$, aryl), $6.39(\mathrm{~s}, 1 \mathrm{H}, \equiv \mathrm{CH}) .{ }^{13} \mathrm{C}-\mathrm{NMR}\left(\mathrm{CDCl}_{3}, 238\right.$
$\mathrm{K}): \delta 203.6$ (trans-CO), 196.0 (cis-CO), 132.0, 131.3, 127.7, 125.5 (aryl), $67.6\left(\equiv \mathrm{C}-\mathrm{C}_{6} \mathrm{H}_{4}\right), 58.4(\equiv \mathrm{C}-\mathrm{H})$.

\subsubsection{Pentacarbonyl $\left(\eta^{2}-\right.$ p-tolylacetylene $)$ chromium (8)}

IR $\left(\mathrm{CH}_{2} \mathrm{Cl}_{2}, 243 \mathrm{~K}\right) v(\mathrm{CO})\left(\mathrm{cm}^{-1}\right): 2074 \mathrm{~m}, 1953 \mathrm{vs}$, 1887 sh. ${ }^{1} \mathrm{H}-\mathrm{NMR}\left(\mathrm{CDCl}_{3}, 238 \mathrm{~K}\right): \delta 7.45-7.08(\mathrm{~m}$, $4 \mathrm{H}$, aryl), $4.81(\mathrm{~s}, 1 \mathrm{H}, \equiv \mathrm{CH}), 2.32\left(\mathrm{~s}, 3 \mathrm{H}, \mathrm{CH}_{3}\right) .{ }^{13} \mathrm{C}-$ NMR $\left(\mathrm{CDCl}_{3}, 238 \mathrm{~K}\right): \delta 224.0$ (trans-CO), 214.8 (cisCO), 140.2, 130.9, 129.6, $119.7\left(\mathrm{C}_{6} \mathrm{H}_{4}\right), 67.8$ (C-Tol), $57.3(\mathrm{C}-\mathrm{H}), 21.5(\mathrm{Me})$.

\subsection{Reaction of $\left(\eta^{2}\right.$-alkyne)pentacarbonylmetal complexes with $N$-phenyl imines}

At $-30^{\circ} \mathrm{C}$, a solution of $N$-phenyl $p$-methylbenzylideneimine, $N$-phenyl benzylideneimine, and $N$-phenyl $p$-chlorbenzylideneimine $\{(\mathrm{Ph}) \mathrm{N}=\mathrm{C}(\mathrm{H}) \mathrm{R}, \quad \mathrm{R}=p$-Tol, $\mathrm{Ph}, p$-chlorphenyl; two equivalents each relative to $\left.\left[\mathrm{M}(\mathrm{CO})_{6}\right]\right\}$, respectively, in 3-4 $\mathrm{ml}$ of $\mathrm{CH}_{2} \mathrm{Cl}_{2}$ was added to a freshly prepared and highly concentrated solution of the acetylene complexes $\mathbf{1}-\mathbf{3}, \mathbf{7}$ and $\mathbf{8}$, respectively. The solution was stirred for $90 \mathrm{~min}$ and gradually warmed to r.t. The solvent was removed in vacuo to give a brown oil. The oil was chromatographed at $-30^{\circ} \mathrm{C}$ on neutral $\mathrm{Al}_{2} \mathrm{O}_{3}$. First, with 5:1 pentane-dichloromethane a yellow band was eluted that contained the 2-azetidin-1-ylidene complexes ( $4 \mathbf{a}-$ $\mathbf{6 a}, 9 \mathbf{a}-\mathbf{1 7} \mathbf{a})$ as a mixture of the syn and anti isomers. Then, with 10:13.5 pentane-dichloromethane a second yellow fraction was eluted, which afforded the amino(ethenyl)carbene complexes $(\mathbf{4 b}-\mathbf{6 b}, \mathbf{9 b}-\mathbf{1 7} \mathbf{b})$ after removal of the solvent in vacuo.

\subsubsection{Pentacarbonyl $\{(2,3,4$-triphenyl)-2-azetidin-1-

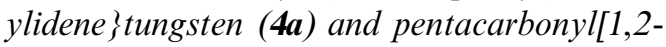 diphenylethenyl(phenylamino)carbene]tungsten (4b)}

Compound 4a. Yield: $0.30 \mathrm{~g}(18 \%$ relative to [W(CO) 6$]$ ). Two isomers: $84 \%$ syn, $16 \%$ anti. M.p. $113^{\circ} \mathrm{C}$. IR $\left(\mathrm{CH}_{2} \mathrm{Cl}_{2}\right) v(\mathrm{CO})\left(\mathrm{cm}^{-1}\right): 2063 \mathrm{~m}, 1929$ vs. ${ }^{1} \mathrm{H}-\mathrm{NMR}\left(\mathrm{CDCl}_{3}\right)$ syn isomer: $\delta 7.73-6.85(\mathrm{~m}, 15 \mathrm{H}, 3$ aryl), $6.56(\mathrm{~d}, J=4.7 \mathrm{~Hz}, 1 \mathrm{H}, 3-\mathrm{CH}), 4.60(\mathrm{~d}, J=4.7$ $\mathrm{Hz}, 1 \mathrm{H}, 4-\mathrm{CH}) .{ }^{1} \mathrm{H}-\mathrm{NMR}\left(\mathrm{CDCl}_{3}\right)$ anti isomer: $\delta 5.83$ $(\mathrm{d}, J=1.7 \mathrm{~Hz}, 1 \mathrm{H}, 3-\mathrm{CH}), 4.01(\mathrm{~d}, J=1.7 \mathrm{~Hz} 1 \mathrm{H}$, 4-CH). ${ }^{13} \mathrm{C}-\mathrm{NMR}\left(\mathrm{CDCl}_{3}\right): \delta 271.2(\mathrm{C} 1), 202.8$ (transCO), 197.4 (cis-CO), 140.2, 130.1, 129.7, 129.6, 129.3, $129.2,129.1,128.7,127.9,127.5,126.6,122.6$ (3 aryl), 78.0 (C3), 66.5 (C4). MS $m / z$ (\%): 607 (15) $\left[\mathrm{M}^{+}\right], 523$ (27) $\left[\mathrm{M}^{+}-3 \mathrm{CO}\right], 467(19)\left[\mathrm{M}^{+}-5 \mathrm{CO}\right], 364(100)\left[\mathrm{M}^{+}\right.$ $-5 \mathrm{CO}-\mathrm{C}-\mathrm{CPh}(\mathrm{H})], \quad 180 \quad$ (23) $\quad\left[\mathrm{M}^{+}-\mathrm{W}(\mathrm{CO})_{5}-\right.$ $\mathrm{C}-\mathrm{CPh}(\mathrm{H})]$. Anal. Found: $\mathrm{C}, 50.91 ; \mathrm{H}, 3.15 ; \mathrm{N}, 2.72$. $\mathrm{C}_{26} \mathrm{H}_{17} \mathrm{NO}_{5} \mathrm{~W}$ (607.3). Calc.: C, 51.38; H, 2.80; N, $2.31 \%$.

Compound 4b. Yield: $0.78 \mathrm{~g}(45 \%$ relative to $\left.\left[\mathrm{W}(\mathrm{CO})_{6}\right]\right)$. M.p. $142^{\circ} \mathrm{C}$. IR $\left(\mathrm{CH}_{2} \mathrm{Cl}_{2}\right) v(\mathrm{CO})\left(\mathrm{cm}^{-1}\right)$ : $2063 \mathrm{~m}, 1929$ vs. ${ }^{1} \mathrm{H}-\mathrm{NMR}\left(\mathrm{CDCl}_{3}\right): \delta 10.25$ (s, br, $1 \mathrm{H}$, $\mathrm{NH}), 7.68-6.90$ (m, 15H, 3 aryl), 6.72, 6.34 (2 s, 
together $1 \mathrm{H}, \mathrm{CH}) .{ }^{13} \mathrm{C}-\mathrm{NMR}\left(\mathrm{CDCl}_{3}\right): \delta 262.5(\mathrm{C} 1)$, 203.5 (trans-CO), 197.8 (cis-CO), 155.6 (C2), 142.2, $136.0,135.0,130.0,129.8,129.6,129.3,128.9,128.6$, $128.3,128.0,127.4,126.9,125.3(3$ aryl + C3). MS $m / z$ (\%): 607 (2) $\left[\mathrm{M}^{+}\right], 523(10)\left[\mathrm{M}^{+}-3 \mathrm{CO}\right], 467$ (19) $\left[\mathrm{M}^{+}-5 \mathrm{CO}\right], 282(15)\left[\mathrm{M}^{+}-\mathrm{W}(\mathrm{CO})_{5}\right], 182(100)\left[\mathrm{M}^{+}\right.$ $\left.-\mathrm{W}(\mathrm{CO})_{5}-\mathrm{C}-\mathrm{CPh}(\mathrm{H})\right]$. Anal. Found: $\mathrm{C}, 51.03 ; \mathrm{H}$, 2.90; N, 2.34. $\mathrm{C}_{26} \mathrm{H}_{17} \mathrm{NO}_{5} \mathrm{~W}$ (607.3). Calc.: C, 51.38; H, $2.80 ; \mathrm{N}, 2.31 \%$.

\subsubsection{Pentacarbonyl[(2-phenyl-3,4-di-p-tolyl)-2-} azetidin-1-ylidene]tungsten (5a) and pentacarbonyl[1,2-p-ditolylethenyl(phenylamino)carbene]tungsten (5b)

Compound 5a. Yield: $0.32 \mathrm{~g}(18 \%$ relative to [W(CO $\left.)_{6}\right]$ ). Two isomers: ca. $90 \%$ syn, $10 \%$ anti. M.p.: $102^{\circ} \mathrm{C}$. IR $\left(\mathrm{CH}_{2} \mathrm{Cl}_{2}\right) v(\mathrm{CO})\left(\mathrm{cm}^{-1}\right): 2061 \mathrm{~m}, 1929$ vs. ${ }^{1} \mathrm{H}-\mathrm{NMR}\left(\mathrm{CDCl}_{3}\right)$ syn isomer: $\delta 7.70-6.77(\mathrm{~m}, 13 \mathrm{H}, 3$ aryl), $6.51(\mathrm{~d}, J=4.6 \mathrm{~Hz}, 1 \mathrm{H}, 3-\mathrm{CH}), 4.53(\mathrm{~d}, J=4.6$ $\mathrm{Hz}, 1 \mathrm{H}, 4-\mathrm{CH}), 2.21,2.15$ (2 s, 6H, $2 \mathrm{Me}) .{ }^{1} \mathrm{H}-\mathrm{NMR}$ $\left(\mathrm{CDCl}_{3}\right)$ anti isomer: $\delta 7.70-6.77(\mathrm{~m}, 13 \mathrm{H}, 3$ aryl $), 5.74$ $(\mathrm{d}, J=1.7 \mathrm{~Hz}, 1 \mathrm{H}, 3-\mathrm{CH}), 3.94(\mathrm{~d}, J=1.7 \mathrm{~Hz}, 1 \mathrm{H}$, 4-CH), 2.38, $2.34(2 \mathrm{~s}, 6 \mathrm{H}, 2 \mathrm{Me}) .{ }^{13} \mathrm{C}-\mathrm{NMR}\left(\mathrm{CDCl}_{3}\right)$ : $\delta 268.9$ (C1), 202.9 (trans-CO), 197.5 (cis-CO), 143.4, $140.1,137.1,131.1,129.9,129.8,129.6,129.1,129.0$, 128.8, 126.7, 122.8, (3 aryl), 78.3 (C3), 66.4 (C4), 21.2, 21.1 (2 Me). MS $m / z(\%): 635$ (8) $\left[\mathrm{M}^{+}\right], 551$ (21)

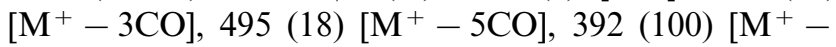
$5 \mathrm{CO}-\mathrm{C}-$ tolyl]. Anal. Found: C, 52.81; H, 3.59; N, 2.36. $\mathrm{C}_{28} \mathrm{H}_{21} \mathrm{NO}_{5} \mathrm{~W}$ (635.3). Calc.: $\mathrm{C}, 52.93 ; \mathrm{H}, 3.33$; N, $2.20 \%$.

Compound 5b. Yield 0.78 g $(43 \%$ relative to [W(CO) $\left.)_{6}\right]$ ). Two isomers: ratio ca. 9:1. M.p. $106^{\circ} \mathrm{C}$. IR $\left(\mathrm{CH}_{2} \mathrm{Cl}_{2}\right) v(\mathrm{CO})\left(\mathrm{cm}^{-1}\right): 2061 \mathrm{~m}, 1929$ vs. ${ }^{1} \mathrm{H}-\mathrm{NMR}$ $\left(\mathrm{CDCl}_{3}\right): \delta 10.04,10.22(2 \mathrm{~s}$, together $1 \mathrm{H}, \mathrm{NH}), 7.52-$ $6.87(\mathrm{~m}, 13 \mathrm{H}, 3$ aryl $), 6.75,6.24(2 \mathrm{~s}$, together $1 \mathrm{H}$, $=\mathrm{CH}), 2.39,2.35,2.27,2.24(4 \mathrm{~s}$, together $6 \mathrm{H}, 2 \mathrm{Me})$. ${ }^{13} \mathrm{C}-\mathrm{NMR}\left(\mathrm{CDCl}_{3}\right): \delta 261.8(\mathrm{C} 1), 203.6$ (trans-CO), $197.9\left(J_{\mathrm{W}, \mathrm{C}}=127.0 \mathrm{~Hz}\right.$, cis-CO), 154.5 (C2), 142.3, $138.7,138.1,137.3,133.1,132.2,130.0,129.7,129.4$, 128.9, 128.8, 126.8, 124.1 (3 aryl $+\mathrm{C} 3), 21.3,21.2(2$ Me). MS $m / z$ (\%): $635(5)\left[\mathrm{M}^{+}\right], 551$ (44) $\left[\mathrm{M}^{+}-3 \mathrm{CO}\right]$, 495 (58) $\left[\mathrm{M}^{+}-5 \mathrm{CO}\right], 310(100)\left[\mathrm{M}^{+}-\mathrm{W}(\mathrm{CO})_{5}\right], 194$ (75) $\left[\mathrm{M}^{+}-\mathrm{W}(\mathrm{CO})_{5}-\mathrm{C}=\mathrm{C}(\right.$ tolyl $\left.) \mathrm{H}\right]$. Anal. Found: $\mathrm{C}$, 53.17; $\mathrm{H}, 3.59 ; \mathrm{N}, 2.36 . \mathrm{C}_{28} \mathrm{H}_{21} \mathrm{NO}_{5} \mathrm{~W}$ (635.3). Calc.: $\mathrm{C}$, $52.93 ; \mathrm{H}, 3.33 ; \mathrm{N}, 2.20 \%$.

\subsubsection{Pentacarbonyl[(2,3,4-triphenyl)-2-azetidin-1- ylidene]chromium (6a) and pentacarbonyl[1,2- diphenylethenyl(phenylamino)carbene]chromium (6b)}

Compound 6a. Yield 0.08 g $(6 \%$ relative to $\left.\left[\mathrm{Cr}(\mathrm{CO})_{6}\right]\right)$. Two isomers: $80 \%$ syn, $20 \%$ anti. M.p. $81^{\circ} \mathrm{C}$. IR $\left(\mathrm{CH}_{2} \mathrm{Cl}_{2}\right) v(\mathrm{CO})\left(\mathrm{cm}^{-1}\right): 2055 \mathrm{~m}, 1933$ vs. ${ }^{1} \mathrm{H}-\mathrm{NMR}\left(\mathrm{CDCl}_{3}\right)$ syn isomer: $\delta 6.64(\mathrm{~d}, J=4.7 \mathrm{~Hz}$, $1 \mathrm{H}, 3-\mathrm{CH}), 4.67(\mathrm{~d}, J=4.7 \mathrm{~Hz}, 1 \mathrm{H}, 4-\mathrm{CH})$ anti isomer: $\delta 7.70-6.87(\mathrm{~m}, 15 \mathrm{H}, 3$ aryl), $5.78(\mathrm{~d}, J=1.7 \mathrm{~Hz}, 1 \mathrm{H}$, $3-\mathrm{CH}), 4.10(\mathrm{~d}, J=1.7 \mathrm{~Hz}, 1 \mathrm{H}, 4-\mathrm{CH}) .{ }^{13} \mathrm{C}-\mathrm{NMR}$
$\left(\mathrm{CDCl}_{3}\right): \delta 139.5,134.1,132.5,129.7,129.6,129.2$, 128.1, 127.9, 127.7, 127.4, 126.3, 123. (3 aryl), 77.9 (C3), $65.4(\mathrm{C} 4)$; anti isomer: $\delta 294.7(\mathrm{C} 1), 222.8$ (transCO), 216.7 (cis-CO), 139.3, 135.2, 129.5, 129.2, 128.9, 128.6, 126.7, 124.6 (3 aryl), 84.2 (C3), 68.1 (C4). MS $m / z(\%): 475$ (7) $\left[\mathrm{M}^{+}\right], 419$ (4) $\left[\mathrm{M}^{+}-2 \mathrm{CO}\right], 391$ (6) $\left[\mathrm{M}^{+}-3 \mathrm{CO}\right], 363(36)\left[\mathrm{M}^{+}-4 \mathrm{CO}\right], 335(100)\left[\mathrm{M}^{+}-\right.$ 5CO]. Anal. Found: C, 65.83; H, 3.88; N, 3.10. $\mathrm{C}_{26} \mathrm{H}_{17} \mathrm{CrNO}_{5}$ (475.5). Calc.: C, 65.69; H, 3.60; N, $2.95 \%$.

Compound 6b: Yield $0.50 \mathrm{~g} \quad(39 \%$ relative to $\left.\left[\mathrm{Cr}(\mathrm{CO})_{6}\right]\right)$. Two isomers: ratio ca. 8:2. M.p. $93^{\circ} \mathrm{C}$. IR $\left(\mathrm{CH}_{2} \mathrm{Cl}_{2}\right) v(\mathrm{CO})\left(\mathrm{cm}^{-1}\right): 2055 \mathrm{~m}, 1933$ vs. ${ }^{1} \mathrm{H}-\mathrm{NMR}$ $\left(\mathrm{CDCl}_{3}\right): \delta 10.47,10.32(2 \mathrm{~s}$, together $1 \mathrm{H}, \mathrm{NH}), 7.59-$ $7.09(\mathrm{~m}, 17 \mathrm{H}, 3$ aryl $), 6.51,6.32(2 \mathrm{~s}$, together $1 \mathrm{H}, \mathrm{CH})$. ${ }^{13} \mathrm{C}-\mathrm{NMR}\left(\mathrm{CDCl}_{3}\right): \delta 284.7(\mathrm{C} 1), 223.7$ (trans-CO), 216.6 (cis-CO), 155.6 (C2), 141.5, 135.4, 135.1, 129.9, 129.8, 129.7, 129.1, 128.8, 128.2, 127.8, 127.1, 123.4 (3 aryl + C3). MS m/z (\%): $475(2)\left[\mathrm{M}^{+}\right], 447(0.5)\left[\mathrm{M}^{+}-\right.$ $\mathrm{CO}], 419$ (1) $\left[\mathrm{M}^{+}-2 \mathrm{CO}\right], 391$ (2) $\left[\mathrm{M}^{+}-3 \mathrm{CO}\right], 363$ (12) $\left[\mathrm{M}^{+}-4 \mathrm{CO}\right], 335$ (43) $\left[\mathrm{M}^{+}-5 \mathrm{CO}\right]$. Correct elemental analysis could not be obtained due to inseparable impurities.

\subsubsection{Pentacarbonyl[(2,4-diphenyl-3-p-tolyl)-2-azetidin-} 1-ylidene]tungsten $(\mathbf{9 a})$ and pentacarbonyl[1-phenyl2-p-tolylethenyl(phenylamino)carbene]tungsten (9b)

Compound 9a. Yield $0.14 \mathrm{~g}(8 \%$ relative to $\left.\left[\mathrm{W}(\mathrm{CO})_{6}\right]\right)$. Two isomers: ca. $90 \%$ syn, $10 \%$ anti. M.p. $113^{\circ} \mathrm{C}$. IR $\left(\mathrm{CH}_{2} \mathrm{Cl}_{2}, 298 \mathrm{~K}\right) v(\mathrm{CO})\left(\mathrm{cm}^{-1}\right): 2062 \mathrm{~m}$, 1929 vs. ${ }^{1} \mathrm{H}-\mathrm{NMR}\left(\mathrm{CDCl}_{3}\right)$ syn isomer: $\delta 7.72-6.78(\mathrm{~m}$, $14 \mathrm{H}, 3$ aryl), 6.52 (d, $J=4.7 \mathrm{~Hz}, 1 \mathrm{H}, 3-\mathrm{CH}), 4.58$ (d, $J=4.7 \mathrm{~Hz}, 1 \mathrm{H}, 4-\mathrm{CH}), 2.13(\mathrm{~s}, 3 \mathrm{H}, \mathrm{Me})$ anti isomer: $\delta$ $7.72-6.78(\mathrm{~m}, 14 \mathrm{H}, 3$ aryl $), 5.80(\mathrm{~d}, J=1.6 \mathrm{~Hz}, 1 \mathrm{H}$, $3-\mathrm{CH}), 4.00(\mathrm{~d}, J=1.6 \mathrm{~Hz}, 1 \mathrm{H}, 4-\mathrm{CH}), 2.34(\mathrm{~s}, 3 \mathrm{H}$, Me). ${ }^{13} \mathrm{C}-\mathrm{NMR}\left(\mathrm{CDCl}_{3}\right): \delta 270.8(\mathrm{C} 1), 202.8$ (transCO), 197.4 (cis-CO), 140.1, 137.7, 134.3, 130.1, 129.7, 129.6, 129.0, 128.9, 128.1, 127.5, 126.6, 122.7 (3 aryl), 78.1 (C3), 66.5 (C4), 21.0 (Me). MS $m / z$ (\%): 621 (11) $\left[\mathrm{M}^{+}\right], 537(23)\left[\mathrm{M}^{+}-3 \mathrm{CO}\right], 481(21)\left[\mathrm{M}^{+}-5 \mathrm{CO}\right], 378$ (100) $\left[\mathrm{M}^{+}-5 \mathrm{CO}-\mathrm{C}(\right.$ tolyl)2H $], \quad 194 \quad$ (33) $\left[\mathrm{M}^{+}-\right.$ $\left.\mathrm{W}(\mathrm{CO})_{5}-\mathrm{C}(\text { tolyl })_{2} \mathrm{H}\right]$. Anal. Found: C, 51.90; H, 3.26; $\mathrm{N}, 2.40 . \mathrm{C}_{27} \mathrm{H}_{19} \mathrm{NO}_{5} \mathrm{~W}$ (621.30). Calc.: C, 52.20; H, $3.08 ; \mathrm{N}, 2.25 \%$.

Compound 9b: Yield $1.09 \mathrm{~g} \quad\left(62^{\%} \%\right.$ relative to [W(CO) $\left.)_{6}\right]$. Two isomers: ratio ca. 7:3. M.p. $123^{\circ} \mathrm{C}$. IR $\left(\mathrm{CH}_{2} \mathrm{Cl}_{2}\right) v(\mathrm{CO})\left(\mathrm{cm}^{-1}\right): 2062 \mathrm{~m}, 1929$ vs. ${ }^{1} \mathrm{H}-\mathrm{NMR}$ $\left(\mathrm{CDCl}_{3}\right): \delta 10.18,10.11(2 \mathrm{~s}$, together $1 \mathrm{H}, \mathrm{NH}), 7.55-$ $7.00(\mathrm{~m}, 14 \mathrm{H}, 3$ aryl $), 6.75,6.33(2 \mathrm{~s}, 1 \mathrm{H}, \mathrm{CH}), 2.29$, 2.25 (3s, together $3 \mathrm{H}, \mathrm{Me}) .{ }^{13} \mathrm{C}-\mathrm{NMR}\left(\mathrm{CDCl}_{3}\right): \delta 260.2$ (C1), 202.7 (trans-CO), 196.6 (cis-CO), 153.4 (C2), $141.0,137.2,135.1,130.7,128.9,128.7,128.5,128.2$, 127.9, 127.7, 126.7, 125.9 (3 aryl + C3), 20.3 (Me). MS $m / z(\%): 621(6)\left[\mathrm{M}^{+}\right], 537(53)\left[\mathrm{M}^{+}-3 \mathrm{CO}\right], 481$ (72) $\left[\mathrm{M}^{+}-5 \mathrm{CO}\right], 296(33)\left[\mathrm{M}^{+}-\mathrm{W}(\mathrm{CO})_{5}\right]$. Anal. Found: 
C, 52.39; $\mathrm{H}, 3.11 ; \mathrm{N}, 2.16 . \mathrm{C}_{27} \mathrm{H}_{19} \mathrm{NO}_{5} \mathrm{~W}$ (621.30). Calc.: C, 52.20; H, 3.08; N, 2.25\%.

\subsubsection{Pentacarbonyl[(3-p-chlorophenyl-2,4-diphenyl)-} 2-azetidin-1-ylidene]tungsten (10a) and pentacarbonyl[2-p-chlorophenyl-1-phenylethenyl(phenylamino)carbene]tungsten $(\mathbf{1 0 b})$

Compound 10a. Yield $0.31 \mathrm{~g}(17 \%$ relative to [W(CO) $\left.)_{6}\right]$ ). Two isomers: $80 \%$ syn, $20 \%$ anti. M.p. $108^{\circ} \mathrm{C}$. IR $\left(\mathrm{CH}_{2} \mathrm{Cl}_{2}\right) v(\mathrm{CO})\left(\mathrm{cm}^{-1}\right): 2063 \mathrm{~m}, 1929$ vs. ${ }^{1} \mathrm{H}-\mathrm{NMR}\left(\mathrm{CDCl}_{3}\right)$ syn isomer: $\delta 7.90-6.73(\mathrm{~m}, 14 \mathrm{H}, 3$ arom.), 6.52 (d, $J=4.8 \mathrm{~Hz}, 1 \mathrm{H}, 3-\mathrm{CH}), 4.60$ (d, $J=4.8$ $\mathrm{Hz}, 1 \mathrm{H}, 4-\mathrm{CH}) .{ }^{1} \mathrm{H}-\mathrm{NMR}\left(\mathrm{CDCl}_{3}\right)$ anti isomer: $\delta 5.80$ (d, $J=1.4 \mathrm{~Hz}, 1 \mathrm{H}, 3-\mathrm{CH}), 3.95(\mathrm{~d}, J=1.6 \mathrm{~Hz}, 1 \mathrm{H}$, 4-CH). ${ }^{13} \mathrm{C}-\mathrm{NMR}\left(\mathrm{CDCl}_{3}\right): \delta 271.2(\mathrm{C} 1), 202.8$ (transCO), 197.4 (cis-CO), 140.1, 134.2, 132.9, 130.1, 129.7, 129.6, 129.2, 129.1, 128.3, 128.1, 122.7 (3 aryl), 78.0 (C3), 66.5 (C4). MS m/z (\%): 641 (11) $\left[\mathrm{M}^{+}\right], 557$ (17) $\left[\mathrm{M}^{+}-3 \mathrm{CO}\right], 501(12)\left[\mathrm{M}^{+}-5 \mathrm{CO}\right], 398(92)\left[\mathrm{M}^{+}-\right.$ $5 \mathrm{CO}-2 \mathrm{C}-2 \mathrm{H}-\mathrm{Ph}], 306(100)\left[\mathrm{M}^{+}-5 \mathrm{CO}-2 \mathrm{C}-\right.$ $2 \mathrm{H}-\mathrm{Ph}-\mathrm{NPh}$. Anal. Found: $\mathrm{C}, 48.68 ; \mathrm{H}, 2.67 ; \mathrm{N}$, 2.60. $\mathrm{C}_{26} \mathrm{H}_{16} \mathrm{ClNO}_{5} \mathrm{~W}$ (641.0). Calc.: C, 48.66; H, 2.51; $\mathrm{N}, 2.18 \%$.

Compound 10b. Yield $0.97 \mathrm{~g} \quad(53 \%$ relative to [W(CO) $)_{6}$; three isomers: $\left.70,20,10 \%\right)$. M.p. $128^{\circ} \mathrm{C}$. IR $\left(\mathrm{CH}_{2} \mathrm{Cl}_{2}\right) v(\mathrm{CO})\left(\mathrm{cm}^{-1}\right): 2063 \mathrm{~m}, 1929$ vs. ${ }^{1} \mathrm{H}-\mathrm{NMR}$ $\left(\mathrm{CDCl}_{3}\right): 10.19,10.34,10.42(3 \mathrm{~s}$, together $1 \mathrm{H}, \mathrm{NH})$, 7.58-6.89 (m, $14 \mathrm{H}, 3$ aryl), 6.67, 6.30, 6.23 (3 s, together $1 \mathrm{H},=\mathrm{CH}) .{ }^{13} \mathrm{C}-\mathrm{NMR}\left(\mathrm{CDCl}_{3}\right): \delta 262.5(\mathrm{C} 1)$, 203.4 (trans-CO), 197.7 (cis-CO), 156.1 (C2), 142.1, $135.6,133.8,133.5,131.2,129.8,129.7,129.4,129.1$, 128.5, 126.9, 125.9 (3 aryl + C3). MS $m / z$ (\%): 641 (7) $\left[\mathrm{M}^{+}\right], 557(40)\left[\mathrm{M}^{+}-3 \mathrm{CO}\right], 501(43)\left[\mathrm{M}^{+}-5 \mathrm{CO}\right], 316$ (100) $\left[\mathrm{M}^{+}-\mathrm{W}(\mathrm{CO})_{5}\right]$. Anal. Found: $\mathrm{C}, 49.11 ; \mathrm{H}, 2.64$; $\mathrm{N}, 2.32 . \mathrm{C}_{26} \mathrm{H}_{16} \mathrm{ClNO}_{5} \mathrm{~W}$ (641.0). Calc.: C, 48.66; H, $2.51 ; \mathrm{N}, 2.18 \%$.

\subsubsection{Pentacarbonyl[(2,3-diphenyl-4-p-tolyl)-2-azetidin-} 1-ylidene]tungsten (11a) and pentacarbonyl[2-phenyl1-p-tolylethenyl(phenylamino)carbene]tungsten (11b)

Compound 11a. Yield: $0.32 \mathrm{~g}(18 \%$ relative to $\left.\left[\mathrm{W}(\mathrm{CO})_{6}\right]\right)$, syn/anti ratio $>97: 3$. M.p. $113^{\circ} \mathrm{C}$. IR $\left(\mathrm{CH}_{2} \mathrm{Cl}_{2}, 298 \mathrm{~K}\right) v(\mathrm{CO})\left(\mathrm{cm}^{-1}\right): 2063 \mathrm{~m}, 1929$ vs. ${ }^{1} \mathrm{H}-\mathrm{NMR}\left(\mathrm{CDCl}_{3}\right): \delta 7.76-6.90(\mathrm{~m}, 14 \mathrm{H}, 3$ aryl $), 6.61$ $(\mathrm{d}, J=4.7 \mathrm{~Hz}, 1 \mathrm{H}, 3-\mathrm{CH}), 4.58(\mathrm{~d}, J=4.7 \mathrm{~Hz}, 1 \mathrm{H}$, 4-CH), 2.13 (s, 3H, Me). ${ }^{13} \mathrm{C}-\mathrm{NMR}\left(\mathrm{CDCl}_{3}\right): \delta 270.1$ (C1), 203.9 (trans-CO), 198.1 (cis-CO), 141.2, 137.5, $134.2,132.6,131.1,130.5,130.2,129.5,129.0,128.6$, 128.0, 124.4 (3 aryl), 80.0 (C3), 66.9 (C4), 21.1 (Me). MS $m / z(\%): 621(17)\left[\mathrm{M}^{+}\right], 537(78)\left[\mathrm{M}^{+}-3 \mathrm{CO}\right], 481$ (100) $\left[\mathrm{M}^{+}-5 \mathrm{CO}\right], 296 \quad(75) \quad\left[\mathrm{M}^{+}-\mathrm{W}(\mathrm{CO})_{5}-\mathrm{H}\right]$. Anal. Found: C, 52.05; H, 3.19; N, 2.48. $\mathrm{C}_{27} \mathrm{H}_{19} \mathrm{NO}_{5} \mathrm{~W}$ (621.3). Calc.: C, 52.20; H, 3.08; N, 2.25\%.

Compound 11b. Yield: $0.84 \mathrm{~g}(48 \%$ relative to $\left.\left[\mathrm{W}(\mathrm{CO})_{6}\right]\right)$. Two isomers ratio ca. 7:3. M.p. $123^{\circ} \mathrm{C}$. IR
$\left(\mathrm{CH}_{2} \mathrm{Cl}_{2}\right) v(\mathrm{CO})\left(\mathrm{cm}^{-1}\right): 2063 \mathrm{~m}, 1929$ vs. ${ }^{1} \mathrm{H}-\mathrm{NMR}$ $\left(\mathrm{CDCl}_{3}\right): \delta 10.13(\mathrm{~s}, \mathrm{br}, 1 \mathrm{H}, \mathrm{NH}), 7.47-6.96(\mathrm{~m}, 14 \mathrm{H}$, 3 aryl), 6.79, 6.33 ( $2 \mathrm{~s}$, together $1 \mathrm{H}, \mathrm{CH}), 2.37,2.26$ (2 $\mathrm{s}$, together $3 \mathrm{H}, \mathrm{Me}) .{ }^{13} \mathrm{C}-\mathrm{NMR}\left(\mathrm{CDCl}_{3}\right): \delta 262.7(\mathrm{C} 1)$, 203.5 (trans-CO), 197.8 (cis-CO), 155.5 (C2), 142.3, $138.9,135.2,132.9,130.0,129.8,129.7,129.6,128.2$, 128.0, 126.9 (3 aryl + C3), $21.4(\mathrm{Me})$. MS $m / z(\%): 621$ (7) $\left[\mathrm{M}^{+}\right], 537(19)\left[\mathrm{M}^{+}-3 \mathrm{CO}\right], 481(36)\left[\mathrm{M}^{+}-5 \mathrm{CO}\right]$, $297(68)\left[\mathrm{M}^{+}-\mathrm{W}(\mathrm{CO})_{5}\right], 205(100)\left[\mathrm{M}^{+}-\mathrm{W}(\mathrm{CO})_{5}-\right.$ $\mathrm{NPh}(\mathrm{H})$ ]. Anal. Found: C, 52.16; H, 3.17; N, 2.32. $\mathrm{C}_{27} \mathrm{H}_{19} \mathrm{O}_{5} \mathrm{NW}$ (621.3). Calc.: C, 52.20; H, 3.08; N, $2.25 \%$.

\subsubsection{Pentacarbonyl[(3-p-chlorophenyl-2-phenyl-4-} p-tolyl)-2-azetidin-1-ylidene]tungsten (12a) and pentacarbonyl[2-p-chlorophenyl-1-p-tolylethenyl(phenylamino)carbene]tungsten (12b)

Compound 12a. Yield $0.30 \mathrm{~g} \quad(16 \%$ relative to [W(CO) $\left.)_{6}\right]$. Two isomers: $94 \%$ syn, $6 \%$ anti. M.p. $108^{\circ} \mathrm{C}$. IR $\left(\mathrm{CH}_{2} \mathrm{Cl}_{2}\right) v(\mathrm{CO})\left(\mathrm{cm}^{-1}\right): 2063 \mathrm{~m}, 1929$ vs. ${ }^{1} \mathrm{H}-\mathrm{NMR}$ $\left(\mathrm{CDCl}_{3}\right)$ syn isomer: $\delta 7.68-6.81(\mathrm{~m}, 13 \mathrm{H}, 3$ aryl $), 6.48$ $(\mathrm{d}, J=4.6 \mathrm{~Hz}, 1 \mathrm{H}, 3-\mathrm{CH}), 4.56(\mathrm{~d}, J=4.7 \mathrm{~Hz}, 1 \mathrm{H}$, 4-CCH), $2.21(\mathrm{~s}, 3 \mathrm{H}, \mathrm{Me})$; anti isomer: $\delta 5.77(\mathrm{~d}$, $J=1.6 \mathrm{~Hz}, 1 \mathrm{H}, 3-\mathrm{CH}), 3.92(\mathrm{~d}, J=1.6 \mathrm{~Hz}, 1 \mathrm{H}, 4-\mathrm{CH})$, $2.31(\mathrm{~s}, 3 \mathrm{H}, \mathrm{Me}) .{ }^{13} \mathrm{C}-\mathrm{NMR}\left(\mathrm{CDCl}_{3}\right): \delta 271.1(\mathrm{C} 1)$, 201.8 (trans-CO), 196.3 (cis-CO), 138.9, 136.4, 132.8, 130.6, 129.8, 128.8, 128.7, 128.0, 127.5, 121.6 (3 aryl), 76.4 (C3), 65.2 (C4), 20.1 (Me). MS $m / z(\%): 655$ (17) $\left[\mathrm{M}^{+}\right], 571(27)\left[\mathrm{M}^{+}-3 \mathrm{CO}\right], 515(15)\left[\mathrm{M}^{+}-5 \mathrm{CO}\right], 412$ (100) $\left[\mathrm{M}^{+}-5 \mathrm{CO}-\mathrm{N}(\mathrm{Ph}) \mathrm{C}\right]$. Anal. Found: $\mathrm{C}$, 49.43; $\mathrm{H}, 2.98 ; \mathrm{N}$ 2.13. $\mathrm{C}_{27} \mathrm{H}_{18} \mathrm{ClNO}_{5} \mathrm{~W}$ (655.7). Calc.: C, 49.41, H, 2.77; N, 2.14\%.

Compound 12b. Yield: $1.14 \mathrm{~g}(61 \%$ relative to $\left.\left[\mathrm{W}(\mathrm{CO})_{6}\right]\right)$. Two isomers: ratio ca. 9:1. M.p.: $127^{\circ} \mathrm{C}$. IR $\left(\mathrm{CH}_{2} \mathrm{Cl}_{2}, 298 \mathrm{~K}\right) v(\mathrm{CO})\left(\mathrm{cm}^{-1}\right): 2063 \mathrm{~m}, 1929$ vs. ${ }^{1} \mathrm{H}-\mathrm{NMR}\left(\mathrm{CDCl}_{3}\right): \delta 10.19(\mathrm{~s}, \mathrm{br}, 1 \mathrm{H}, \mathrm{NH}), 7.65-7.02$ $(\mathrm{m}, 13 \mathrm{H}, \operatorname{aryl}), 6.69(\mathrm{~s}, 1 \mathrm{H},=\mathrm{CH}), 2.39,2.36(2 \mathrm{~s}$, together $3 \mathrm{H}, \mathrm{Me}) .{ }^{13} \mathrm{C}-\mathrm{NMR}\left(\mathrm{CDCl}_{3}\right): \delta 260.5(\mathrm{Cl})$, 202.8 (trans-CO), $196.5\left(J_{\mathrm{w}, \mathrm{C}}=128.3 \mathrm{~Hz}\right.$, cis-CO $)$, 154.7 (C2), 140.9, 138.0, 132.4, 131.3, 130.1, 128.9, 128.7, 128.6, 128.3, 127.3, 125.7, 123.7 (3 aryl + C3), $20.4(\mathrm{Me}) . \mathrm{MS} m / z(\%): 655(11)\left[\mathrm{M}^{+}\right], 571(100)$ $\left[\mathrm{M}^{+}-3 \mathrm{CO}\right], 515(64)\left[\mathrm{M}^{+}-5 \mathrm{CO}\right], 412(63)\left[\mathrm{M}^{+}-\right.$ $5 \mathrm{CO}-\mathrm{N}(\mathrm{Ph}) \mathrm{C}]$. Anal. Found: C, 49.43; H, 2.98; N 2.13. $\mathrm{C}_{27} \mathrm{H}_{18} \mathrm{ClNO}_{5} \mathrm{~W}$ (655.7). Calc.: C, 49.41; H, 2.77; $\mathrm{N}, 2.14 \%$.

\subsection{8. [(4-p-Bromophenyl-2,3-diphenyl)-2-azetidin-1-} ylidene]pentacarbonyltungsten (13a) and [1-p-bromophenyl-2-phenylethenyl(phenylamino)carbene]-

pentacarbonyltungsten (13b)

Compound 13a. Yield: 0.38 g $(20 \%$ relative to [W(CO $\left.)_{6}\right]$ ). Two isomers: $90 \%$ syn, $10 \%$ anti. M.p. $113^{\circ} \mathrm{C}$. IR $\left(\mathrm{CH}_{2} \mathrm{Cl}_{2}\right) v(\mathrm{CO})\left(\mathrm{cm}^{-1}\right): 2064 \mathrm{~m}, 1931$ vs. ${ }^{1} \mathrm{H}-\mathrm{NMR}\left(\mathrm{CDCl}_{3}\right)$ syn isomer: $\delta 7.72-6.85(\mathrm{~m}, 14 \mathrm{H}, 3$ 
aryl), $6.56(\mathrm{~d}, J=4.7 \mathrm{~Hz}, 1 \mathrm{H}, 3-\mathrm{CH}), 4.56(\mathrm{~d}, J=4.7$ $\mathrm{Hz}, 1 \mathrm{H}, 4-\mathrm{CH}) .{ }^{1} \mathrm{H}-\mathrm{NMR}\left(\mathrm{CDCl}_{3}\right)$ anti isomer: $\delta 5.76$ $(\mathrm{d}, J=1.6 \mathrm{~Hz}, 1 \mathrm{H}, 3-\mathrm{CH}), 3.97(\mathrm{~d}, J=1.6 \mathrm{~Hz}, 1 \mathrm{H}$, 4-CH). ${ }^{13} \mathrm{C}-\mathrm{NMR}\left(\mathrm{CDCl}_{3}\right): \delta 269.1(\mathrm{C} 1), 203.0$ (transCO), 196.3 (cis-CO), 138.9, 132.3, 131.6, 131.2, 130.6, 130.3, 128.7, 128.6, 128.3, 127.5, 125.4, 121.6 ( 3 aryl), 82.5 (C3, syn), 76.8 (C3, anti), $67.6(\mathrm{C} 4$, anti), 64.7 (C4, syn). MS m/z (\%): 685 (10) [M+], 603 (14) $\left[\mathrm{M}^{+}-\right.$ 3CO], 545 (10) [ $\mathrm{M}^{+}-5 \mathrm{CO}$. Anal. Found: C, 45.57; H, 2.84; N, 1.94. $\mathrm{C}_{26} \mathrm{H}_{16} \mathrm{BrNO}_{5} \mathrm{~W}$ (686.2). Calc.: C, 45.51; H, 2.35; N, 2.04 .

Compound 13b. Yield: $0.87 \mathrm{~g}(45 \%$ relative to [W(CO) $\left.)_{6}\right]$. Two isomers: ratio ca. 8:2. M.p. $131^{\circ} \mathrm{C}$. IR $\left(\mathrm{CH}_{2} \mathrm{Cl}_{2}\right) v(\mathrm{CO})\left(\mathrm{cm}^{-1}\right): 2063 \mathrm{~m}, 1930$ vs. ${ }^{1} \mathrm{H}-\mathrm{NMR}$ $\left(\mathrm{CDCl}_{3}\right): \delta 10.35,10.23(\mathrm{~s}, \mathrm{br}, 1 \mathrm{H}, \mathrm{NH}), 7.59-7.07$ (m, $14 \mathrm{H}, 3$ aryl), 6.34, $6.70(2 \mathrm{~s}$, together $1 \mathrm{H}, \mathrm{CH}) .{ }^{13} \mathrm{C}-$ NMR $\left(\mathrm{CDCl}_{3}\right): \delta 262.5(\mathrm{C} 1), 203.3$ (trans-CO), 197.6 $\left(J_{\mathrm{W}, \mathrm{C}}=106 \mathrm{~Hz}\right.$, cis-CO), 154.8 (C2), 142.0, 134.9, 134.6, 132.4, 132.0, 131.4, 130.0, 129.9, 129.7, 128.7, $126.8(3$ aryl $+\mathrm{C} 3)$. MS $m / z(\%): 687(0.6)\left[\mathrm{M}^{+}\right], 601$ (4) $\left[\mathrm{M}^{+}-3 \mathrm{CO}\right], 545$ (4) $\left[\mathrm{M}^{+}-5 \mathrm{CO}\right], 360(100)\left[\mathrm{M}^{+}\right.$ $\left.-\mathrm{W}(\mathrm{CO})_{5}\right]$. Anal. Found: C, 45.78; H, 2.58; N, 2.33 . $\mathrm{C}_{26} \mathrm{H}_{16} \mathrm{BrNO}_{5} \mathrm{~W}$ (686.2). Calc.: C, 45.51; H, 2.35; N, $2.04 \%$.

\subsection{9. [(4-p-Bromophenyl-2-phenyl-3-p-tolyl)-2-} azetidin-1-ylidene]pentacarbonyltungsten (14a) and [1-p-bromophenyl-2-tolylethenyl(phenylamino)carbene]pentacarbonyltungsten (14b)

Compound 14a. Yield 0.16 g $(8 \%$ relative to [W(CO $\left.\left.)_{6}\right]\right)$. Two isomers: $75 \%$ syn, $25 \%$ anti. M.p. $113^{\circ} \mathrm{C}$. IR $\left(\mathrm{CH}_{2} \mathrm{Cl}_{2}\right) v(\mathrm{CO})\left(\mathrm{cm}^{-1}\right): 2062 \mathrm{~m}, 1929$ vs. ${ }^{1} \mathrm{H}-\mathrm{NMR}\left(\mathrm{CDCl}_{3}\right)$ syn isomer: $\delta 7.69-6.75(\mathrm{~m}, 13 \mathrm{H}, 3$ aryl), $6.51(\mathrm{~d}, J=4.6 \mathrm{~Hz}, 1 \mathrm{H}, 3-\mathrm{CH}), 4.53(\mathrm{~d}, J=4.7$ $\mathrm{Hz}, 1 \mathrm{H}, 4-\mathrm{CH}), 2.17$ (s, 3H, Me). ${ }^{1} \mathrm{H}-\mathrm{NMR}\left(\mathrm{CDCl}_{3}\right)$ anti isomer: $\delta 5.71(\mathrm{~d}, J=1.6 \mathrm{~Hz}, 1 \mathrm{H}, 3-\mathrm{CH}), 3.95(\mathrm{~d}$, $J=1.6 \mathrm{~Hz}, 1 \mathrm{H}, 4-\mathrm{CH}), 2.34$ (s, 3H, Me). ${ }^{13} \mathrm{C}-\mathrm{NMR}$ $\left(\mathrm{CDCl}_{3}\right)$ syn isomer: $\delta 268.5(\mathrm{C1}), 202.9$ (trans-CO), 197.2 (cis-CO), 139.6, 139.2, 134.6, 132.0, 130.7, 130.3, $130.0,129.5,129.4,126.5,123.3,122.1$ (3 aryl), 82.7 (C3), $68.4(\mathrm{C} 4), 21.3(\mathrm{Me})$; anti isomer: $\delta 5.71(\mathrm{~d}$, $J=1.6 \mathrm{~Hz}, 1 \mathrm{H}, 3-\mathrm{CH}), 3.95(\mathrm{~d}, J=1.6 \mathrm{~Hz}, 1 \mathrm{H}, 4-\mathrm{CH})$, $2.34(\mathrm{~s}, 3 \mathrm{H}, \mathrm{Me}) .{ }^{13} \mathrm{C}-\mathrm{NMR}\left(\mathrm{CDCl}_{3}\right)$ syn isomer: $\delta$ 269.5 (C1), 203.2 (trans-CO), 197.7 (cis-CO), 139.9, $138.4,133.7,132.0,131.7,130.1,129.7,129.6,129.5$, 126.8, 122.8, 122.1 (3 aryl), 77.7 (C3), 65.8 (C4), 21.2 (Me). MS $m / z(\%): 701$ (13) $\left[\mathrm{M}^{+}\right], 617$ (28) $\left[\mathrm{M}^{+}-\right.$ $3 \mathrm{CO}], 559(22)\left[\mathrm{M}^{+}-5 \mathrm{CO}\right], 456(83)\left[\mathrm{M}^{+}-5 \mathrm{CO}-\right.$ $\mathrm{C}-\mathrm{N}(\mathrm{Ph})], \quad 272 \quad(28) \quad\left[\mathrm{M}^{+}-\mathrm{W}(\mathrm{CO})_{5}-\mathrm{C}-\mathrm{N}(\mathrm{Ph})\right]$. Anal. Found: $\mathrm{C}, \quad 45.95 ; \mathrm{H}, \quad 2.91 ; \mathrm{N}, 2.28$. $\mathrm{C}_{27} \mathrm{H}_{18} \mathrm{BrNO}_{5} \mathrm{~W}$ (700.2). Calc.: C, 46.32; H, 2.59; N, $2.00 \%$.

Compound 14b. Yield 0.89 g $(45 \%$ relative to $\left.\left[\mathrm{W}(\mathrm{CO})_{6}\right]\right)$. Two isomers: ratio ca. 9:1. M.p. $132^{\circ} \mathrm{C}$. IR
$\left(\mathrm{CH}_{2} \mathrm{Cl}_{2}, 298 \mathrm{~K}\right) v(\mathrm{CO})\left(\mathrm{cm}^{-1}\right): 2062 \mathrm{~m}, 1929$ vs. ${ }^{1} \mathrm{H}-\mathrm{NMR}\left(\mathrm{CDCl}_{3}\right): \delta 10.16,10.24(2 \mathrm{~s}$, together $1 \mathrm{H}$, $\mathrm{NH}), 7.58-6.97$ (m, $13 \mathrm{H}, 3$ aryl), 6.67, $6.29(2 \mathrm{~s}, 1 \mathrm{H}$, $\mathrm{CH}), 2.38,2.25(2 \mathrm{~s}$, together $3 \mathrm{H}, \mathrm{Me}) .{ }^{13} \mathrm{C}-\mathrm{NMR}$ $\left(\mathrm{CDCl}_{3}\right): \delta 262.3(\mathrm{C} 1), 203.3$ (trans-CO), 197.7 (cisCO), 154.0 (C2), 142.1, 138.5, 135.2, 132.4, 132.0, $131.7,131.5,131.1,129.9,129.8,129.2,126.9,123.0(3$ aryl $+\mathrm{C} 3), 21.3(\mathrm{Me})$. MS $m / z(\%): 701(8)\left[\mathrm{M}^{+}\right], 617$ (73) $\left[\mathrm{M}^{+}-3 \mathrm{CO}\right], 559(87)\left[\mathrm{M}^{+}-5 \mathrm{CO}\right], 377(100)\left[\mathrm{M}^{+}\right.$ $\left.-\mathrm{W}(\mathrm{CO})_{5}\right]$. Anal. Found: C, 46.32; H, 2.87; N, 2.12. $\mathrm{C}_{27} \mathrm{H}_{18} \mathrm{BrNO}_{5} \mathrm{~W}$ (700.2). Calc.: C, 46.32; H, 2.59; N, $2.00 \%$.

\subsubsection{Pentacarbonyl[(2,4-diphenyl-3-p-tolyl)-2- azetidin-1-ylidene]chromium (15a) and pentacarbonyl[1-phenyl-2-tolylethenyl(phenylamino)- carbene]chromium (15b)}

Compound 15a. Yield $0.07 \mathrm{~g} \quad(5 \%$ relative to $\left.\left[\mathrm{Cr}(\mathrm{CO})_{6}\right]\right)$. Two isomers: $90 \%$ syn, $10 \%$ anti. M.p. $80^{\circ} \mathrm{C}$. IR $\left(\mathrm{CH}_{2} \mathrm{Cl}_{2}\right) v(\mathrm{CO})\left(\mathrm{cm}^{-1}\right): 2055 \mathrm{~m}, 1933$ vs. ${ }^{1} \mathrm{H}-\mathrm{NMR}\left(\mathrm{CDCl}_{3}\right)$ syn isomer: $\delta 7.67-6.76(\mathrm{~m}, 14 \mathrm{H}, 3$ aryl), 6.59 (d, $J=4.3 \mathrm{~Hz}, 1 \mathrm{H}, 3-\mathrm{CH}), 4.65$ (d, $J=4.5$ $\mathrm{Hz}, 1 \mathrm{H}, 4-\mathrm{CH}), 2.13(\mathrm{~s}, 3 \mathrm{H}, \mathrm{Me})$. anti isomer: $\delta 5.81(\mathrm{~d}$, $J=1.6 \mathrm{~Hz}, 1 \mathrm{H}, 3-\mathrm{CH}), 3.96(\mathrm{~d}, J=1.6 \mathrm{~Hz}, 1 \mathrm{H}, 4-\mathrm{CH})$. ${ }^{13} \mathrm{C}-\mathrm{NMR}\left(\mathrm{CDCl}_{3}\right): \delta 294.8(\mathrm{C} 1), 223.0$ (trans-CO), 217.2 (cis-CO), 140.0, 138.0, 134.7, 130.3, 130.1, 129.8, $129.7,129.3,128.5,127.9,126.9,123.6$ (3 aryl), 78.5 (C3), 66.0 (C4), $21.6(\mathrm{Me}) . \mathrm{MS} m / z(\%): 489(5)\left[\mathrm{M}^{+}\right]$, 433 (3) $\left[\mathrm{M}^{+}-2 \mathrm{CO}\right], 405$ (4) $\left[\mathrm{M}^{+}-3 \mathrm{CO}\right], 377$ (4) $\left[\mathrm{M}^{+}-4 \mathrm{CO}\right], 349$ (77) $\left[\mathrm{M}^{+}-5 \mathrm{CO}\right.$. Anal. Found: $\mathrm{C}$, $66.29 ; \mathrm{H}, 4.45 ; \mathrm{N}, 2.89 . \mathrm{C}_{27} \mathrm{H}_{19} \mathrm{CrNO}_{5} \cdot 0.14$ pentane $(489.5+10.1)$. Calc.: C, 66.54; H, 4.14; N, 2.80\%.

Compound 15b. Yield $0.57 \mathrm{~g}(43 \%$ relative to $\left.\left[\mathrm{Cr}(\mathrm{CO})_{6}\right]\right)$. Two isomers: ratio ca. 8:2. M.p. $104^{\circ} \mathrm{C}$. IR $\left(\mathrm{CH}_{2} \mathrm{Cl}_{2}\right) v(\mathrm{CO})\left(\mathrm{cm}^{-1}\right): 2055 \mathrm{~m}, 1933$ vs. ${ }^{1} \mathrm{H}-\mathrm{NMR}$ $\left(\mathrm{CDCl}_{3}\right): \delta 10.38,10.51(2 \mathrm{~s}$, together $1 \mathrm{H}, \mathrm{NH}), 7.68-$ $6.92(\mathrm{~m}, 14 \mathrm{H}, 3$ aryl $), 6.50,6.25(2 \mathrm{~s}$, together $1 \mathrm{H}, \mathrm{CH})$, 2.31, $2.27(2 \mathrm{~s}$, together $3 \mathrm{H}, \mathrm{Me}) .{ }^{13} \mathrm{C}-\mathrm{NMR}\left(\mathrm{CDCl}_{3}\right): \delta$ 284.3 (C1), 223.7 (trans-CO), 216.7 (cis-CO), 154.9, 160.4 (2 C2), 141.6, 137.9, 137.4, 135.7, 132.4, 132.2, $129.9,129.8,129.7,129.6,129.5,129.2,129.1,129.0$, $128.9,128.8,128.7,128.3,128.2,127.9,127.1,124.8$, 124.8, 124.3, 124.1, 120.9 (6 aryl + C3), 21.2, $21.6(2$ Me). MS $m / z(\%): 489$ (2) $\left[\mathrm{M}^{+}\right], 461$ (3) $\left[\mathrm{M}^{+}-\mathrm{CO}\right]$, 433 (3) $\left[\mathrm{M}^{+}-2 \mathrm{CO}\right], 405$ (12) $\left[\mathrm{M}^{+}-3 \mathrm{CO}\right], 349$ (100) $\left[\mathrm{M}^{+}-5 \mathrm{CO}\right]$. Anal. Found: C, 65.61; H, 4.01; N, 2.96 . $\mathrm{C}_{27} \mathrm{H}_{19} \mathrm{CrNO}_{5}$ (489.5). Calc.: C, 66.26; H, 3.91; N, $2.86 \%$.

\subsubsection{Pentacarbonyl[(2,3-diphenyl-4-p-tolyl)-2- azetidin-1-ylidene]chromium (16a) and pentacarbonyl[(2-phenyl-1-tolylethenyl(phenylamino)- carbene]chromium (16b)}

Compound 16a. Yield $0.07 \mathrm{~g} \quad(5 \%$ relative to $\left.\left[\mathrm{Cr}(\mathrm{CO})_{6}\right]\right)$. Two isomers: $80 \%$ syn, $20 \%$ anti. M.p. 
$79^{\circ} \mathrm{C}$. IR $\left(\mathrm{CH}_{2} \mathrm{Cl}_{2}\right) v(\mathrm{CO})\left(\mathrm{cm}^{-1}\right): 2055 \mathrm{~m}, 1933$ vs. ${ }^{1} \mathrm{H}-\mathrm{NMR}\left(\mathrm{CDCl}_{3}\right)$ syn isomer: $\delta 7.68-6.87(\mathrm{~m}, 14 \mathrm{H}, 3$ aryl), $6.60(\mathrm{~d}, J=4.5 \mathrm{~Hz}, 1 \mathrm{H}, 3-\mathrm{CH}), 4.62(\mathrm{~d}, J=4.5$ $\mathrm{Hz}, 1 \mathrm{H}, 4-\mathrm{CH}), 2.17$ (s, 3H, Me); anti isomer: $\delta 7.68-$ $6.87(\mathrm{~m}, 14 \mathrm{H}, 3 \operatorname{aryl}), 5.71(\mathrm{~d}, J=1.6 \mathrm{~Hz}, 1 \mathrm{H}, 3-\mathrm{CH})$, 4.07 (d, $J=1.7 \mathrm{~Hz}, 1 \mathrm{H}, 4-\mathrm{CH}), 2.37$ (s, 3H, Me). ${ }^{13} \mathrm{C}-\mathrm{NMR}\left(\mathrm{CDCl}_{3}\right): \delta 296.0(\mathrm{C} 1), 222.8$ (trans-CO), 216.9 (cis-CO), 140.0, 137.1, 133.0, 131.1, 129.8, 129.7, $129.5,129.2,128.7,128.2,126.5,123.4$, (3 aryl), 84.7 (C3, anti $), 78.5(\mathrm{C} 3$, syn $), 68.1(\mathrm{C} 4$, anti $), 65.8(\mathrm{C} 4$, syn), 21.2 (Me, anti), 21.1(Me, syn). MS $m / z$ (\%): 489 (6) $\left[\mathrm{M}^{+}\right], 405(5)\left[\mathrm{M}^{+}-3 \mathrm{CO}\right], 378(22)\left[\mathrm{M}^{+}-4 \mathrm{CO}\right]$; 349 (86) $\left[\mathrm{M}^{+}-5 \mathrm{CO}\right], 296$ (7) $\left[\mathrm{M}^{+}-\mathrm{Cr}(\mathrm{CO})_{5}-\mathrm{H}\right]$. Anal. Found: C, 66.09; $\mathrm{H}, \quad 4.02 ; \mathrm{N}, 3.03$. $\mathrm{C}_{27} \mathrm{H}_{19} \mathrm{CrNO}_{5}$ (489.45). Calc.: C, 66.26; H, 3.91; N, $2.86 \%$.

Compound 16b. Yield $0.62 \mathrm{~g}(46 \%$ relative to $\left.\left[\mathrm{Cr}(\mathrm{CO})_{6}\right]\right)$. Two isomers: ratio ca. 7:3. M.p. $105^{\circ} \mathrm{C}$. IR $\left(\mathrm{CH}_{2} \mathrm{Cl}_{2}\right) v(\mathrm{CO})\left(\mathrm{cm}^{-1}\right): 2055 \mathrm{~m}, 1933$ vs. ${ }^{1} \mathrm{H}-\mathrm{NMR}$ $\left(\mathrm{CDCl}_{3}\right): \delta 10.34,10.64(2 \mathrm{~s}$, together $1 \mathrm{H}, \mathrm{NH}), 7.55-$ $7.03(\mathrm{~m}, 14 \mathrm{H}, 3$ aryl $), 6.47,6.18(2 \mathrm{~s}$, together $1 \mathrm{H}$, $\mathrm{CH}), 2.36,2.27(2 \mathrm{~s}$, together $3 \mathrm{H}, \mathrm{Me}) .{ }^{13} \mathrm{C}-\mathrm{NMR}$ $\left(\mathrm{CDCl}_{3}\right): \delta 284.6(\mathrm{C} 1), 223.8$ (trans-CO), 216.7 (cis$\mathrm{CO}), 155.6$ (C2), 141.6, 138.8, 138.0, 135.3, 132.3, 129.9, 129.7, 129.6, 129.2, 128.2, 127.1, 123.4 (3 aryl + C3), $21.3(\mathrm{Me})$. MS m/z (\%): 489 (2) $\left[\mathrm{M}^{+}\right], 461$ (3) $\left[\mathrm{M}^{+}-\mathrm{CO}\right], 433$ (1) $\left[\mathrm{M}^{+}-2 \mathrm{CO}\right], 405$ (15) $\left[\mathrm{M}^{+}-\right.$ 3CO], 349 (100) $\left[\mathrm{M}^{+}-5 \mathrm{CO}\right], 296 \quad(50) \quad\left[\mathrm{M}^{+}-\right.$ $\left.\mathrm{Cr}(\mathrm{CO})_{5}-\mathrm{H}\right]$. Anal. Found: C, 66.54; H, 4.05; N 2.92. $\mathrm{C}_{27} \mathrm{H}_{19} \mathrm{CrNO}_{5}$ (489.5). Calc.: C, 66.26; H, 3.91; N, $2.86 \%$.

\subsubsection{Pentacarbonyl[(3-p-chlorophenyl-2-phenyl-4-p- tolyl)-2-azetidin-1-ylidene]chromium (17a) and pentacarbonyl[2-p-chlorophenyl-1-tolylethenyl(phenylami no)carbene]chromium (17b)}

Compound 17a. Yield 0.08 g $(6 \%$ relative to $\left.\left[\mathrm{Cr}(\mathrm{CO})_{6}\right]\right)$. Two isomers syn/anti $>9: 1$. M.p. $73^{\circ} \mathrm{C}$. IR $\left(\mathrm{CH}_{2} \mathrm{Cl}_{2}\right) v(\mathrm{CO})\left(\mathrm{cm}^{-1}\right): 2055 \mathrm{~m}, 1934$ vs. ${ }^{1} \mathrm{H}-\mathrm{NMR}$ (acetone- $d_{6}$ ): syn isomer: $\delta 8.00-7.02(\mathrm{~m}, 14 \mathrm{H}, 3$ aryl + 3-CH), $4.91(\mathrm{~d}, J=4.5 \mathrm{~Hz}, 1 \mathrm{H}, 4-\mathrm{CH}), 2.18$ (s, $3 \mathrm{H}, \mathrm{Me})$; anti isomer: $\delta 8.00-7.02(\mathrm{~m}, 14 \mathrm{H}, 3$ aryl $+3-$ $\mathrm{CH}), 5.70(\mathrm{~d}, J=1.5 \mathrm{~Hz}, 3-\mathrm{CH}), 04.05(\mathrm{~d}, J=1.5 \mathrm{~Hz}$, $1 \mathrm{H}, 4-\mathrm{CH}$ ), 2.22 (s, 3H, Me); ${ }^{13} \mathrm{C}-\mathrm{NMR}$ (acetone- $d_{6}$ ): $\delta 293.8$ (C1), 223.9 (trans-CO), 217.6 (cis-CO), 133.7, $133.1,132.4,130.9,130.6,130.4,130.0,129.8,129.6$, 129.1, 125.0, 117.7 (3 aryl), 79.5 (C3), 66.4 (C4), 21.2 (Me). MS $m / z(\%): 523(5)\left[\mathrm{M}^{+}\right], 495(1)\left[\mathrm{M}^{+}-\mathrm{CO}\right]$, 467 (2) $\left[\mathrm{M}^{+}-2 \mathrm{CO}\right], 439$ (4) $\left[\mathrm{M}^{+}-3 \mathrm{CO}\right], 411$ (33) $\left[\mathrm{M}^{+}-4 \mathrm{CO}\right], 383(100)\left[\mathrm{M}^{+}-5 \mathrm{CO}\right]$. Correct elemental analysis could not be obtained due to inseparable impurities.

Compound 17b. Yield $0.56 \mathrm{~g}(39 \%$ relative to $\left.\left[\mathrm{Cr}(\mathrm{CO})_{6}\right]\right)$. Two isomers syn/anti ratio ca. 7:3. IR $\left(\mathrm{CH}_{2} \mathrm{Cl}_{2}\right) v(\mathrm{CO})\left(\mathrm{cm}^{-1}\right): 2055 \mathrm{~m}, 1934$ vs. ${ }^{1} \mathrm{H}-\mathrm{NMR}$ $\left(\mathrm{CDCl}_{3}\right): \delta 10.69,10.56(2 \mathrm{~s}$, together $1 \mathrm{H}, \mathrm{NH}), 7.51-$ $6.77(\mathrm{~m}, 13 \mathrm{H}, 3$ aryl $), 6.30,6.10(2 \mathrm{~s}$, together $1 \mathrm{H}$, $\mathrm{CH}), 2.36,2.26(2 \mathrm{~s}$, together $3 \mathrm{H}, \mathrm{Me}) .{ }^{13} \mathrm{C}-\mathrm{NMR}$ $\left(\mathrm{CDCl}_{3}\right): \delta$ 287.4, $282.5(2 \mathrm{C} 1), 223.8,223.1$ (2 trans CO), 216.8, 216.4 (2 cis-CO), 155.6, 149.7 (2 C2), $141.3,139.4,138.8,138.2,133.9,133.5,132.9,132.6$, $131.5,130.9$. 130.3, 129.7, 129.6, 129.5, 129.2, 129.0, $128.2,126.9,123.9,121.5,119.9(6$ aryl +2 C3), 21.3, $21.2(2 \mathrm{Me})$. MS $m / z(\%): 523(0.4)\left[\mathrm{M}^{+}\right], 495$ (2) $\left[\mathrm{M}^{+}-\mathrm{CO}\right], 467(0.5)\left[\mathrm{M}^{+}-2 \mathrm{CO}\right], 439$ (9) $\left[\mathrm{M}^{+}-\right.$ $3 \mathrm{CO}], \quad 383 \quad(63) \quad\left[\mathrm{M}^{+}-5 \mathrm{CO}\right], 330 \quad(41) \quad\left[\mathrm{M}^{+}-\right.$ $\left.\mathrm{Cr}(\mathrm{CO})_{5}-\mathrm{H}\right]$. Anal. Found: C, 61.98; H, 3.77; N, 3.07. $\mathrm{C}_{27} \mathrm{H}_{18} \mathrm{ClCrNO}_{5}$ (523.9). Calc.: C, 61.90; H, 3.46; $\mathrm{N}, 2.67 \%$.

\section{4. $X$-ray structural analysis of $\mathbf{1 1 b}$}

$\mathrm{C}_{27} \mathrm{H}_{19} \mathrm{NO}_{5} \mathrm{~W}$, molecular mass (621.30), crystal size $0.2 \times 0.2 \times 0.2 \mathrm{~mm}^{3}$ (obtained by recrystallization from $3: 1$ pentane-dichloromethane at $-30^{\circ} \mathrm{C}$ ); crystal system triclinic, space group $P \overline{1}, a=8.785(3), \quad b=$ 12.254(7), $\quad c=12.798(5) \quad \AA, \quad \alpha=102.15(4)$, $\beta=105.42(3), \gamma=95.97(4)^{\circ} ; V=1279.6(10) \AA^{3}, Z=2$, $D_{\text {calc }}=1.723 \mathrm{~g} \mathrm{~cm}^{-1}, \lambda\left(\mathrm{Mo}-\mathrm{K}_{\alpha}\right)=0.71073 \AA, F(000)$ 646 ; Wyckoff scan, $2 \theta$ range $4.0-54.0^{\circ}$, scan rate variable $2.0-29.3^{\circ} \mathrm{min}^{-1}$ in $\omega$; 5589 independent reflections, 4680 reflections with $F>4 \sigma(F) ; 319$ refined parameters; $R=0.033, R_{\mathrm{w}}=0.035$. Largest difference peak and hole: +0.77 and -1.13 e $\AA^{-3}$ ). The measurements were performed at $-26^{\circ} \mathrm{C}$, with a crystal of 11b mounted in a glass capillary on a Siemens $R 3 \mathrm{~m} / \mathrm{V}$ diffractometer (graphite monochromator, Mo- $\mathrm{K}_{\alpha}$ radiation, $\lambda=0.71073 \AA$ ). A semi-empirical absorption correction (based on ten reflections) was carried out. The structure was solved by Patterson methods using the SHELXTL-PLUS (VMS) program package. The positions of the hydrogen atoms were calculated by assuming ideal geometry $\left(d_{\mathrm{C}-\mathrm{H}}=0.96 \AA\right)$, and their coordinates were refined together with those of the attached $\mathrm{C}$ atoms as 'riding models'. The positions of all other atoms were refined anisotropically by the full-matrix least-squares method.

\section{Supplementary material}

Crystallographic data for the structural analysis of $\left[(\mathrm{CO})_{5} \mathrm{~W}=\mathrm{C}(\mathrm{NPhH}) \mathrm{C}\left(\mathrm{C}_{6} \mathrm{H}_{4} \mathrm{Me}-p\right)=\mathrm{C}(\mathrm{Ph}) \mathrm{H}\right] \cdot 1 / 2 \mathrm{CH}_{2} \mathrm{Cl}_{2}$ (11b) have been deposited with the Cambridge Crystallographic Data Centre as supplementary publication no. CCDC 136352. Copies of this information may be obtained free of charge from: The Director, CCDC, 12 Union Road, Cambridge, CB2 1EZ, UK (Fax: + 441223-336033; e-mail: deposit@ccdc.cam.ac.uk or www: http://www.ccdc.cam.ac.uk). 


\section{Acknowledgements}

Support of these investigations by the Deutscher Akademischer Austauschdienst (grant for M.M. A.-E.), the Volkswagen-Stiftung and the Fonds der Chemischen Industrie is gratefully acknowledged.

\section{References}

[1] See e.g. (a) J. March, Advanced Organic Chemistry, third ed., Wiley, New York, 1985, p. 869. (b) W.T. Brady in: S. Patai (Ed.), The Chemistry of Ketenes, Alkenes and Related Compounds, Wiley, New York, 1980, p. 279. (c) T.T. Tidwell, Ketenes, Wiley, New York, 1995.

[2] A.G.M. Barrett, J. Mortier, M. Sabat, M.A. Sturgess, Organometallics 7 (1988) 2553.

[3] (a) A.G.M. Barrett, M.A. Sturgess, Tetrahedron Lett. 27 (1986) 3811. (b) A.G.M. Barrett, M.A. Sturgess, J. Org. Chem. 52 (1987) 3940.

[4] M.R. Terry, L.A. Mercando, C. Kelley, G.L. Geoffroy, P. Nombel, N. Lugan, R. Mathieu, R.L. Ostrander, B.E. OwensWaltermire, A.L. Rheingold, Organometallics 13 (1994) 843.

[5] H. Fischer, A. Schlageter, W. Bidell, A. Früh, Organometallics 10 (1991) 389.

[6] K. Weiss, E.O. Fischer, J. Müller, J. Chem. Ber. 107 (1974) 3548.

[7] A.G.M. Barrett, C.P. Brock, M.A. Sturgess, Organometallics 4 (1985) 1903.

[8] M.M. Abd-Elzaher, H. Fischer, J. Organomet. Chem. 588 (1999) 235.
[9] H. Fischer, H.-P. Volkland, R. Stumpf, An. Quim. 92 (1996) 148.

[10] (a) K.H. Dötz, W. Kuhn, K. Ackermann, Z. Naturforsch. Teil B 38 (1983) 1351. (b) U. Schubert, K.H. Dötz, Z. Naturforsch. Teil B 39 (1984) 1624.

[11] E. Pohl, B.O. Kneisel, R. Herbst-Irmer, A. de Meijere, F. Funke, F. Stein, Acta Crystallogr. Sect. C 51 (1995) 2503.

[12] A. Wienand, H.-U. Reissig, H. Fischer, J. Hofmann, Chem. Ber. 122 (1989) 1589.

[13] R. Pipoh, R. van Eldik, G. Henkel, Organometallics 12 (1993) 2236.

[14] (a) A. Parlier, H. Rudler, J. Chem. Soc. Chem. Commun. (1986) 514. (b) H. Le Bozec, C. Cosset, P.H. Dixneuf, J. Chem. Soc. Chem. Commun. (1991) 881.

[15] H. Fischer, H.-P. Volkland, A. Früh, R. Stumpf, J. Organomet. Chem. 491 (1995) 267.

[16] For a review see e.g. H. Fischer, in: K.H. Dötz, H. Fischer, P. Hofmann, F.R. Kreissl, U. Schubert, K. Weiss (Eds.), Transition Metal Carbene Complexes, Verlag Chemie, Weinheim, 1983, p. 1.

[17] See e.g. (a) E.O. Fischer, F.R.Kreissl, J. Organomet. Chem. 35 (1972) C47. (b) E.O. Fischer, H.J. Kalder, J. Organomet. Chem. 131 (1977) 57.

[18] For a recent review see: R. Aumann, H. Nienaber, Adv. Organomet. Chem. 41 (1997) 163.

[19] See e.g. (a) K.H. Dötz, C.G. Kreiter, J. Organomet. Chem. 99 (1975) 309. (b) K.H. Dötz, Chem. Ber. 110 (1977) 78.

[20] (a) A. Hantzsch, Ber. 34 (1901) 833. (b) R.W. Layer, Chem. Rev. 63 (1963) 489. (c) F. Texier-Boullet, Synthesis (1985) 679.

[21] R. Adams, L.F. Fieser, A.H. Blatt, J.R. Johnson, in: Organic Reactions, vol. V, Wiley, New York, 1949, p. 50. 